\title{
Kebijakan Optimalisasi Pemungutan Pajak Daerah dalam Upaya Meningkatkan Pendapatan Asli Daerah Kota Bandung : Suatu Pendekatan Analytical Hierarchy Process
}

\author{
Bayu Kharisma \\ ${ }^{1}$ Departemen Ilmu Ekonomi, Fakultas Ekonomi dan Bisnis, Universitas Padjadjaran \\ Jl. Dipati Ukur No. 35 Bandung, 40132, Indonesia \\ bayu.kharisma@unpad.ac.id
}

\begin{abstract}
Abstrak
Tujuan penelitian ini adalah untuk menentukan berbagai faktor dalam kemampuan keuangan daerah untuk meningkatkan Pendapatan Asli Daerah (PAD) yang bersumber dari pajak daerah dan merumuskan berbagai alternatif kebijakan untuk meningkatkan Pendapatan Asli Daerah (PAD) yang bersumber dari pajak daerah di Kota Bandung. Adapun Metode penelitian yang digunakan dalam penelitian ini adalah Analytical Hierarchy Process (AHP). Faktor-faktor yang dipertimbangkan dalam menentukan kemampuan keuangan daerah untuk meningkatkan keuangan daerah, khususnya peningkatan pendapatan asli daerah yang bersumber dari pajak daerah di Kota Bandung adalah : (1) Meningkatkan keleluasaan Pemerintah Daerah dalam merencanakan program pembangunan di daerah; (2) Penyediaan dan peningkatan kualitas pelayanan publik kepada masyarakat; (3) Peran pajak yang tergolong kecil dalam total penerimaan daerah; (4) Lemahnya mekanisme dan pengawasan dan perencanaan keuangan; (5) Masih rendahnya motivasi dan kesadaran masyarakat untuk membayar pajak daerah; (6) Kemampuan administrasi pemungutan di daerah yang belum efektif. Berbagai alternatif kebijakan berdasarkan urutan prioritasnya yang mungkin dapat dilaksanakan dalam upaya meningkatkan keuangan daerah, khususnya peningkatan PAD yang bersumber dari pajak daerah di Kota Bandung adalah : (1) Meningkatkan efisiensi administrasi pemungutan di daerah dan menekan biaya pemungutan yang berlebihan; (2) Memperluas basis penerimaan pajak daerah dan memperkuat proses pemungutan; (3) Pelaksanaan mekanisme pengawasan serta perencanaan keuangan yang lebih baik; (4) Sosialisasi dan penyuluhan untuk mendorong kesadaran masyarakat dalam membayar pajak daerah; (5) Memperbesar kewenangan perpajakan daerah (local taxing power).
\end{abstract}

Kata kunci: Pendapatan Asli Daerah (PAD), Pajak Daerah, Analytical Hierarchy Process (AHP), Keuangan Daerah, Alternatif-alternatif kebijakan

\begin{abstract}
The purpose of this study was to determine various factors in the ability of regional finances to increase own source revenue (PAD) sourced from local taxes and formulate various policy alternatives to increase own source revenue (PAD) sourced from local taxes in the City of Bandung. The research method used in this study is Analytical Hierarchy Process (AHP). Factors considered in determining regional financial capacity to improve regional finances, in particular the increase in local revenues derived from local taxes in the city of Bandung are: (1) increasing the flexibility of regional governments in planning development programs in the regions; (2) provision and improvement of the quality of public services to the community; (3) the role of tax which is classified as small in total regional revenues; (4) weak mechanisms and supervision and financial planning; (5) the lack of motivation and awareness of the public to pay local taxes; (6) administrative capacity of collection in areas that have not been effective. various alternative policies based on the order of priorities that might be implemented in an effort to improve regional finance, especially the increase in local revenue derived from local taxes in the city of bandung are: (1) increasing the efficiency of the administration of collection in the regions and reducing excessive collection costs; (2) expanding the base of local tax revenue and strengthening the collection process; (3) better implementation of supervision mechanisms and financial planning; (4) socialization and counseling to encourage public awareness in paying local taxes; (5) enlarge local taxing power.
\end{abstract}

Keywords: own source revenue (PAD), local taxes, Analytical Hierarchy Process (AHP), ability of regional finances, policy alternatives 


\section{LATAR BELAKANG}

Pada tahun 2001 Indonesia sudah memasuki era baru dalam bentuk pemerintahan, yaitu era otonomi daerah. Menurut skenario yang diyakini sebagian besar masyarakat sekarang ini, saat itulah UU No. 22/1999 tentang Pemerintahan Daerah dan UU No.25/1999 yang kemudian direvisi melalui UU 32 dan UU 33 tahun 2004. Kedua Undang-Undang ini merupakan perwujudan atas penyelenggaraan otonomi daerah yang memberikan kewenangan yang luas, nyata, dan bertanggung jawab kepada daerah yang secara proporsional diwujudkan dalam bentuk, pembagian, dan pemanfaatan sumber daya nasional yang berkeadilan serta adanya perimbangan keuangan pusat dan daerah.

Pada dasarnya terdapat dua landasan ekonomi bagi pelaksanaan otonomi daerah. Pertama adalah menyangkut alokasi sumberdaya yang efisien (Musgrave \& Musgrave, 1989). Kemampuan daerah untuk mengelola sumberdaya secara efisien tercermin dari kebijakan yang diterapkan oleh pemerintah daerah selaku perencana, dimana hal ini akan membawa dampak pada keberhasilan perekonomian suatu daerah secara optimal dan efisien. Sistem pemerintahan yang sentralistik membawa dampak kurang menguntungkan bagi pemerintah daerah karena setiap kebijakan harus dikoordinasikan dengan pemerintah pusat sehingga tidak efektif. Kedua adalah meningkatkan kemampuan pemerintah daerah untuk mendorong inovasi dan kreativitas dalam rangka memenuhi kebutuhan masyarakat dan peningkatan kemakmuran rakyat di daerah tersebut (Sidik, 2003). Dengan demikian, adanya otonomi daerah maka setiap daerah diharapkan mampu mengembangkan potensi, baik sumber daya alam maupun sumberdaya manusia untuk meningkatkan kemakmuran bagi masyarakat daerah.

Penyelenggaraan otonomi daerah, penyaluran, pembagian, dan pemanfaatan sumber daya nasional yang berkeadilan serta perimbangan keuangan pusat dan daerah dimaksudkan dalam rangka mempertahankan, memperkokoh Negara Kesatuan Republik Indonesia dilaksanakan berdasarkan asas kerakyatan yang berkesinambungan dengan pengawasan dewan perwakilan rakyat daerah (DPRD) dan masyarakat. Sesuai dengan semangat tersebut maka paradigma pemerintahan 
daerah yang dikembangkan menurut kedua undang-undang tersebut adalah bertumpu pada nilai-nilai demokrasi, peran serta masyarakat, pemerataan, keadilan, serta memperhatikan potensi dan keanekaragaman daerah. Disamping itu, juga dimaksudkan untuk mendorong memberdayakan masyarakat, membutuhkan prakarsa dan kreatifitas, meningkatkan peran serta masyarakat serta mengembangkan peran dan fungsi Dewan Perwakilan Rakyat Daerah (DPRD). Dengan paradigma demikian, maka pemerintah daerah dituntut untuk menyelenggarakan kegiatan pemerintahan yang mengarah kepada terciptanya good governance, yaitu penyelenggaraan pemerintahan yang berkeadilan, partisipatif, transparan, dan akuntabel.

Dalam rangka meningkatkan kemampuan keuangan daerah agar dapat melaksanakan otonomi, Pemerintah melakukan berbagai kebijakan perpajakan daerah, diantaranya dengan menetapkan UU No.28 Tahun 2009 tentang Pajak dan Retribusi Daerah. Pemberian kewenangan dalam pengenaan pajak dan retribusi daerah, diharapkan dapat lebih mendorong Pemerintah Daerah terus berupaya untuk mengoptimalkan PAD, khususnya yang berasal dari pajak daerah. Pada era otonomi daerah, daerah diberikan kewenangan yang lebih besar untuk mengatur dan mengurus rumah tangganya sendiri. Tujuannya antara lain adalah untuk lebih mendekatkan pelayanan pemerintah kepada masyarakat, memudahkan masyarakat untuk memantau dan mengontrol penggunaan dana yang bersumber dari Anggaran Pendapatan dan Belanja Daerah (APBD) dan menciptakan persaingan yang sehat antar daerah dan mendorong timbulnya inovasi. Sejalan dengan kewenangan tersebut, Pemerintah Daerah diharapkan lebih mampu menggali sumber-sumber keuangan khususnya untuk memenuhi kebutuhan pembiayaan pemerintahan dan pembangunan di daerahnya melalui Pendapatan Asli Daerah (PAD). Tuntutan peningkatan PAD semakin besar seiring dengan semakin banyaknya kewenangan pemerintahan yang dilimpahkan kepada daerah disertai pengalihan personil, peralatan, pembiayaan dan dokumentasi ke daerah dalam jumlah besar.

Pemberlakuan otonomi daerah telah berjalan hampir 17 Tahun. Sampai saat ini usulan pemekaran daerah selalu ada. Sebagai catatan, saat ini Indonesia terdiri dari 34 Provinsi dan 514 Kabupaten/Kota. Sayangnya merujuk pada perkembangan penerapan sistem 
otonomi daerah ini, nampaknya belum sesuai dengan harapan. Otonomi daerah yang diterapkan belum memperlihatkan peningkatan kemandirian daerah. Kemandirian daerah ini secara teori salah satunya dapat diukur dengan melihat pencapaian Pendapatan Asli Daerah (PAD). PAD sendiri bersumber dari pendapatan pajak, retribusi, hasil pengelolaan kekayaan daerah yang dipisahkan dan lain-lain PAD yang sah.

Gambar 1. Derajat Otonomi Fiskal Provinsi

(Proporsi PAD Terhadap Total Pendapatan TA 2016)

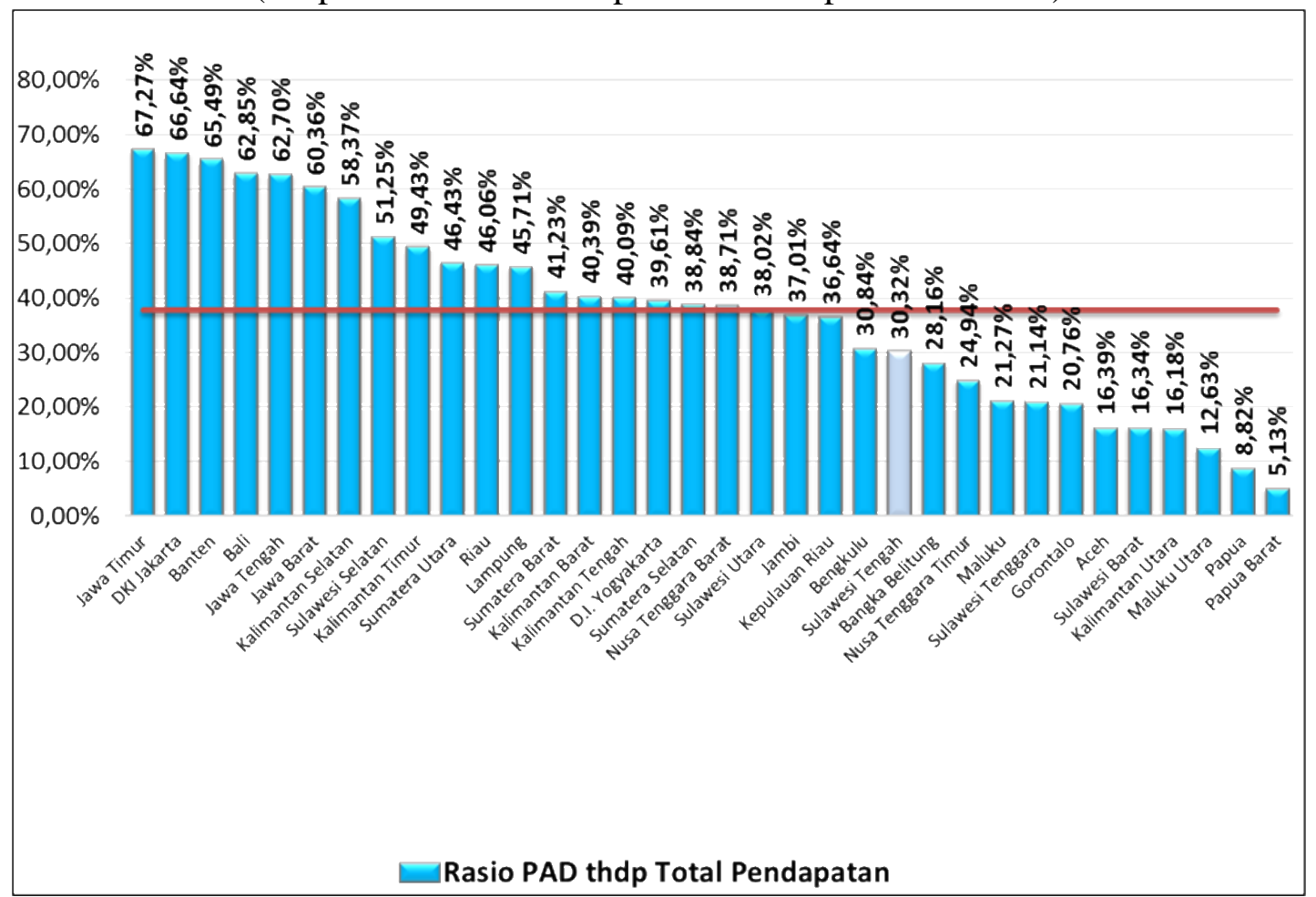

Sumber: Perda APBD, Ditjen Bina Keuangan Daerah Kementerian Dalam Negeri, 2016.

Berdasarkan Gambar 1. Dapat dilihat bahwa sampai tahun 2016, rata-rata PAD berdasarkan provinsi baru mencapai 37,82 persen. Belum ada daerah yang prosentase PAD terhadap pendapatan daerahnya mencapai 70 persen. Daerah yang mencapai prosentase di atas 50 persen baru 8 daerah, sementara daerah yang berada di bawah 30 persen ada 11 daerah, bahkan 8 masih ada 2 daerah yang di bawah 10 persen. Dengan demikian, sebagian daerah di Indonesia memiliki proporsi dana perimbangan melebihi 50 persen yang bermakna daerah belum memperlihatkan kemandiriannya dan masih sangat tergantung bantuan dari pusat untuk membiayai segala kewajibannya terkait dengan pembangunan dan pemerintahan. 
Ditinjau dari kontribusi pajak Daerah dan retribusi Daerah, distribusi kewenangan perpajakan antara Daerah dengan Pusat terjadi ketimpangan yang relatif besar. Peranan pajak dalam pembiayaan Daerah yang sangat rendah dan sangat bervariasi juga terjadi karena adanya perbedaan yang cukup besar dalam jumlah penduduk, kondisi geografis, dan kemampuan masyarakat (Sidik, 2002). Hal serupa terjadi di di Jawa barat, khususnya Kota Bandung, dimana tingkat capaian rata-rata penerimaan daerah Kota Bandung melalui Pajak Daerah pada tahun anggaran 2016 tidak memenuhi target. Dalam hal ini, target pada tahun 2016 target penerimaan pajak pada tahun 2016 sebesar Rp.2.186.416.770.000, sedangkan realisasinya hanya mencapai Rp. 1.720.491.187.627 atau capaian target mencapai 78, 69\%. Tidak tercapainya capaian pada penerimaan pajak daerah karena ada beberapa jenis pajak yang tidak memenuhi target yang direncanakan, misalnya pajak BPHTB dan pajak ait tanah. Lebih jelasnya dapat dilihat pada Tabel 1. berikut ini.

Tabel 1.

Target, Realisasi dan Capaian Penerimaan Pajak Daerah Tahun 2016

\begin{tabular}{|c|c|c|c|c|c|}
\hline NO & $\begin{array}{l}\text { INDIKATOR } \\
\text { KINERJA }\end{array}$ & SATUAN & $\begin{array}{c}\text { TARGET } \\
\text { TAHUN } 2016\end{array}$ & $\begin{array}{l}\text { REALISASI } \\
\text { TAHUN } 2016\end{array}$ & $\begin{array}{c}\text { CAPAIAN } \\
(\%)\end{array}$ \\
\hline \multirow{10}{*}{1.} & $\begin{array}{l}\text { Jumlah } \\
\text { Penerimaan } \\
\text { pajak daerah : }\end{array}$ & \multirow{10}{*}{ Rp. } & 2.186 .416 .770 .000 & 1.720 .491 .187 .627 & $78,69 \%$ \\
\hline & 1. Pajak Hotel & & 260.000 .000 .000 & 274.809 .381 .603 & $105,70 \%$ \\
\hline & 2. Pajak Restoran & & 235.000 .000 .000 & 241.788 .513 .937 & $102,89 \%$ \\
\hline & 3. Pajak Hiburan & & 68.000 .000 .000 & 69.831 .106 .484 & $102,69 \%$ \\
\hline & 4. Pajak Parkir & & 26.000 .000 .000 & 29.289 .132 .387 & $112,65 \%$ \\
\hline & 5. Pajak BPHTB & & 660.000 .000 .000 & 440.329 .093 .979 & $66,72 \%$ \\
\hline & 6. PPJ & & 173.200 .000 .000 & 177.358 .328 .595 & $102,40 \%$ \\
\hline & 7. Pajak Reklame & & 316.716 .770 .000 & 25.653 .533 .922 & $8,10 \%$ \\
\hline & $\begin{array}{l}\text { 8. Pajak Air } \\
\text { Tanah }\end{array}$ & & 32.500 .000 .000 & 33.686 .169 .278 & $103,65 \%$ \\
\hline & 9. PBB & & 415.000 .000 .000 & 427.745 .927 .442 & $103,07 \%$ \\
\hline 2. & $\begin{array}{l}\text { IKM bidang } \\
\text { pelayanan pajak } \\
\text { daerah. }\end{array}$ & Nilai & 82 & 83,545 & $101,88 \%$ \\
\hline \multicolumn{3}{|c|}{ Rata-rata Capaian IKU } & \multicolumn{3}{|c|}{$90,29 \%$} \\
\hline \multicolumn{3}{|c|}{ Kinerja Capaian Sasaran } & \multicolumn{3}{|c|}{ Tidak Tercapai } \\
\hline
\end{tabular}

Sumber : LKIP Dinas Pelayanan Pajak Kota Bandung Tahun 2016 
Berdasarkan fakta dan permasalahan mengenai kontribusi pajak yang tidak memenuhi target yang direncanakan maka penelitian ini bertujuan untuk menentukan dan menganalisa elemen-elemen yang perlu dipertimbangkan dalam menentukan kemampuan keuangan daerah untuk meningkatkan Pendapatan Asli Daerah (PAD) yang bersumber dari pajak daerah dan merumuskan alternatif-alternatif kebijakan untuk meningkatkan Pendapatan Asli Daerah (PAD) yang bersumber dari pajak daerah di Kota Bandung. Dengan demikian, adanya alternatif kebijakan tersebut diharapkan sekaligus dapat menghilangkan upaya Daerah untuk menggali sumbersumber PAD yang berdampak distortif terhadap perekonomian di Kota Bandung. Oleh karena itu, dengan meningkatnya kontribusi PAD, khususnya dari pajak daerah terhadap kebutuhan pembiayaan pembangunan daerah secara tidak langsung akan berdampak kepada kemandirian daerah dalam merencanakan program-program pembangunan, khususnya di Kota Bandung.

\section{PENELITIAN TERDAHULU}

Hasil-hasil penelitian sebelumnya antara lain dikemukakan oleh hasil penelitian Subhan Purwadinata pada tahun 2010 tentang Analisis Potensi Pendapatan Asli Daerah dan Strategi Peningkatan Kemampuan Keuangan Daerah (Studi di Kabupaten Sumbawa). Hasil penelitian tersebut menunjukkan bahwa: (1) Potensi pendapatan Kabupaten Sumbawa didominasi dari sektor retribusi daerah sedangkan pajak daerah mengikuti tetapi keseluruhan pendapatan masih banyak dipenuhi oleh dana perimbangan dari pusat dan kontribusi PAD belum mampu membentuk kemandirian daerah. (2) Penataan administrasi pajak daerah terkendala oleh belum optimalnya pelaksanaan Sosialisasi, Mendata, Menagih tiap hari dalam kegiatan pemungutan pajak daerah.(3) Kemampuan keuangan dari potensi PAD sangat rendah dan membutuhkan pemanfaatan optimal potensi yang dimiliki daerah. (4) Kontribusi komponen PAD yang mengalami penurunan drastis yakni dari sektor pajak, dan kontribusinya jauh lebih rendah dari kontribusi retribusi daerah. (5) Pemerintah daerah dalam kebijakannya memperioritaskan penerimaan daerah dari sektor pajak daerah. 
Andriani dan Purnawan (2017) dalam penelitiannya di Jawa Tengah menunjukkan bahwa pengaturan pajak daerah di Pemerintahan Provinsi Jawa Tengah belum secara optimal dapat meningkatkan sumber pendapatan asli daerah. Hal ini dapat dilihat dari hasil realisasi pungutan pajak daerah dan kontribusi pajak daerah terhadap Pendapatan Asli Daerah di Provinsi Jawa Tengah. Para eksekutif maupun legislatif belum secara optimal menggali semua potensi yang ada, baik potensi Sumber Daya Alam, Sumber Daya Manusia maupun pemanfaatan jasa-jasa tertentu yang dimiliki oleh pemerintah daerah. Sehingga pengaturan pajak daerah di Provinsi Jawa Tengah sebelum mampu untuk meningkatkan sumber Pendapatan Asli daerah di Provinsi Jawa Tengah. Hal tersebut disebabkan terlalu rendahnya pemerintahan Provinsi Jawa Tengah menetapkan target untuk pajak daerah. Seharusnya untuk meningkatan pendapatan asli daerah maka pemerintah dapat meningkatkan target, walaupun akibatnya persentase pencapaian realisasi lebih rendah dari persentase pencapaian target. Karena target sudah dicapai, biasanya usaha untuk meningkatkan PAD menjadi menjadi lemah. Pemerintah juga terlalu terpaku pada UU No. 28 Tahun 2009 sehingga tidak mencari sumber-sumber PAD baru yang perlu dipertimbangkan untuk dilaksanakan secara efektif, efisien, ekonomis, produktif, inovatif, insentif dan menyakinkan.

Penelitiaan lainnya yang relevan telah dilaksanakan pula oleh Mohammad Riduansyah pada tahun 2003 dengan topik Kontribusi Pajak Daerah Dan Retribusi Daerah Terhadap Pendapatan Asli Daerah (PAD) Dan Anggaran Pendapatan dan Belanja Daerah (APBD) Guna Mendukung Pelaksanaan Otonomi Daerah (Studi Kasus Pemerintah Daerah Kota Bogor). Masalah yang dikaji dalam penelitian ini adalah sejauhmana kontribusi penerimaan pajak daerah dan retribusi daerah terhadap perolehan pendapatan asli daerah, khususnya pada Pemerintah Daerah Kota Bogor sebagai studi kasus. Hasil penelitian ini menunjukkan bahwa Kontribusi penerimaan pajak daerah dan retribusi daerah terhadap perolehan PAD Pemerintah Kota Bogor dalam kurun waktu Tahun Anggaran (TA) 1993/1994 - 2000 cukup signifikan dengan rata-rata kontribusi sebesar $27,78 \%$ per tahun. Kontribusi penerimaan pajak daerah dan retribusi daerah terhadap total perolehan penerimaan Pemerintah Daerah Kota Bogor tercermin dalam APBD-nya, dikaitkan dengan kemampuannya untuk 
melaksanakan otonomi daerah terlihat cukup baik. Komponen pajak daerah dalam kurun waktu TA 1993/1994 - 2000 rata-rata pertahunnya memberikan kontribusi sebesar 7,81\% per tahun dengan rata-rata pertumbuhan sebesar 22,89\% pertahunnya. Sedangkan pendapatan yang berasal dari komponen retribusi daerah, pada kurun waktu yang sama, memberikan kontribusi rata-rata per tahunnya sebesar 15,61\% dengan rata-rata pertumbuhan pertahunnya sebesar 5,08\% per tahun.

Elfayang Rizky Ayu Puspitasari (2014) melakukan studi mengenai Analisis Efektivitas, Efisiensi, dan Kontribusi Pajak serta Retribusi Daerah Terhadap PAD Kabupaten Blora selama Tahun 2009-2013. Hasil penelitiannya menunjukkan bahwa Hasil dari penelitian adalah: (1) Tingkat efektivitas untuk pajak daerah dan retribusi daerah selama tahun 2009-2013 masuk dalam kategori sangat efektif. (2) Tingkat efisiensi untuk pajak daerah dan retribusi daerah dari tahun 2009 sampai 2013 secara keseluruhan berada pada tingkat efisien. (3) Kontribusi pajak daerah terhadap pendapatan asli daerah Kabupaten Blora dari tahun 2009 sampai dengan tahun 2013 kurang berkontribusi. Namun tingkat rasio kontribusinya cenderung naik. (4) Kontribusi retribusi daerah terhadap pendapatan asli daerah Kabupaten Blora dari tahun 2009-2013 berkontribusi sedang tetapi rasio kontribusinya cenderung turun setiap tahunnya. (5) Analisis uji beda t-tes untuk efektivitas dan efisiensi untuk pajak daerah dan retribusi daerah tidak menunjukkan perbedaan, sedangkan untuk kontribusi pajak daerah dan retribusi daerah menunjukkan perbedaan diantara keduanya

\section{METODOLOGI}

Metode penelitian yang digunakan dalam menggambarkan Kebijakan Optimalisasi Pemungutan Pajak Daerah dalam Upaya Meningkatkan Pendapatan Asli Daerah Kota Bandung yaitu pendekatan Analytical Hierarchy Process. Analytical Hierarchy Process, yang selanjutnya disebut AHP merupakan metodologi yang komprehensif dan sangat berguna, yang memiliki kemampuan untuk menyatukan faktor kualitatif dan kuantitatif dalam proses pengambilan keputusan. AHP menggunakan model hirarki yang terdiri dari tujuan, kriteria, beberapa tingkat subkriteria dan alternatif untuk setiap permasalahan dan keputusan. Model AHP memakai persepsi manusia 
yang dianggap "ekspert" sebagai input utamanya. Kriteria "ekspert" mengacu pada orang yang mengerti benar permasalahan yang diajukan, merasakan akibat suatu masalah atau mempunyai kepentingan terhadap masalah tersebut. Untuk membuat keputusan dengan model AHP pada umumnya dilakukan dengan menggunakan lebih dari satu responden atau lebih dari satu "ekspert". Penggunaan ini dilakukan karena suatu masalah harus dipecahkan dari berbagai sudut pandang.

Dalam perkembangannya, AHP tidak saja digunakan untuk menentukan prioritas pilihan-pilihan dengan banyak kriteria, tetapi penerapannya telah meluas sebagai metode alternatif untuk menyelesaikan bermacam-macam masalah, seperti memilih portofolio, analisis manfaat biaya, peramalan dan lain-lain. Dalam menyelesaikan persoalan dengan menggunakan model AHP perlu dilakukan beberapa langkah antara lain :

\section{Decomposition}

Setelah persoalan didefinisikan dengan baik, maka perlu dilakukan dekomposisi, yaitu memecah persoalan yang utuh menjadi unsur-unsurnya. Apabila ingin mendapatkan hasil yang akurat, maka pemecahan juga dilakukan terhadap unsurunsurnya sampai tidak mungkin dilakukan pemecahan lebih lanjut, sehingga didapatkan beberapa tingkatan dari persoalan tersebut. Dekomposisi mencakup tiga proses yang berurutan dan saling berhubungan, yaitu identifikasi level dan elemen, definisi konsep dan formulasi pertanyaan.

\section{Comparative Judgment}

Prinsip ini berarti membuat penilaian tentang kepentingan relatif dari dua elemen pada suatu tingkat tertentu dalam kaitannya dengan tingkat diatasnya. Penilaian ini merupakan inti dari AHP, karena hal tersebut akan berpengaruh terhadap prioritas elemen-elemen. Hasil dari penilaian ini akan tampak lebih jelas apabila diperlihatkan dalam bentuk matriks yang dinamakan matriks pairwise comparison. Agar diperoleh skala yang bermanfaat ketika membandingkan dua elemen, maka seorang responden yang akan memberikan jawaban perlu pengertian yang komprehensif dan menyeluruh tentang elemen-elemen yang dibandingkan dan relevansinya terhadap kriteria atau tujuan yang dipelajari. Dalam penyusunan skala kepentingan ini, digunakan beberapa ukuran 1 sampai 
dengan 9. Skala perbandingan ini disebut dengan skala fundamental yang diturunkan berdasarkan riset psikologis Saaty atas kemampuan individu dalam membuat suatu perbandingan secara berpasangan terhadap beberapa elemen yang diperbandingkan.

Tabel 2. Skala Perbandingan Berpasangan Analitical Hierarchy Process

\begin{tabular}{|c|c|c|}
\hline Tingkat & Definisi & Keterangan \\
\hline 1 & $\begin{array}{l}\text { Kedua elemen adalah } \\
\text { sama penting }\end{array}$ & $\begin{array}{l}\text { Kedua elemen memiliki } \\
\text { pengaruh yang sama }\end{array}$ \\
\hline 3 & $\begin{array}{l}\text { Elemen yang satu sedikit } \\
\text { lebih penting daripada } \\
\text { yang lainnya }\end{array}$ & $\begin{array}{l}\text { Penilaian sedikit lebih } \\
\text { memihak pada salah satu } \\
\text { elemen disbanding pasaganya } \\
\text { (moderat) }\end{array}$ \\
\hline 5 & $\begin{array}{l}\text { Elemen yang satu lebih } \\
\text { penting daripada yang } \\
\text { lannya }\end{array}$ & $\begin{array}{l}\text { Salah satu elemen sangat } \\
\text { berpengaruh dan dominasinya } \\
\text { tampak secara nyata }\end{array}$ \\
\hline 7 & $\begin{array}{l}\text { Elemen yang satu jelas } \\
\text { sangat penting daripada } \\
\text { elemen yang lainnya }\end{array}$ & $\begin{array}{l}\text { Bukti bahwa salah satu elemen } \\
\text { sangat penting daripada } \\
\text { pasangannya adalah sangat } \\
\text { jelas }\end{array}$ \\
\hline 9 & $\begin{array}{l}\text { Elemen yang satu mutlak } \\
\text { sangat penting daripada } \\
\text { elemen yang lainnya }\end{array}$ & $\begin{array}{l}\text { Bukti bahwa salah satu elemen } \\
\text { sangat penting daripada } \\
\text { pasangannya adalah sangat } \\
\text { jelas }\end{array}$ \\
\hline $2,4,6,8$ & $\begin{array}{l}\text { Nilai tengah di antara dua } \\
\text { perbandingan yang } \\
\text { berdekatan }\end{array}$ & $\begin{array}{l}\text { Nilai ini diberikan jika } \\
\text { terdapat keraguan di antara } \\
\text { kedua penilaian } \\
\text { berdekatan }\end{array}$ \\
\hline $\begin{array}{c}\text { Kebalikannya } \\
\text { (reciprocal) }\end{array}$ & \multicolumn{2}{|c|}{$\begin{array}{l}\text { Jika elemen x mempunyai salah satu nilai di atas pada saat } \\
\text { dibandingkan dengan elemen y, maka elemen y mempunyai } \\
\text { nilai kebalikan bila dibandingkan dengan elemen x }\end{array}$} \\
\hline
\end{tabular}

Sumber : Saaty, 1989

\section{Synthesis of Priority}

Setelah matriks perbandingan untuk sekelompok elemen selesai dibentuk, maka langkah selanjutnya adalah mengukur bobot prioritas setiap elemen tersebut dengan dasar persepsi seorang ekspert yang telah dimasukkan dalam matriks tersebut. Dari setiap matriks pairwise comparison kemudian dicari eigenvectornya untuk mendapatkan local priority. Karena matriks pairwise comparison terdapat pada setiap tingkat, maka untuk medapatkan global priority harus dilakukan sintesa di antara local priority. Prosedur melakukan sintesa 
berbeda menurut bentuk hirarki. Pengurutan elemen-elemen menurut kepentingan relatif melalui prosedur sintesa dinamakan prioriy setting.

\section{Logical Consistency}

Konsistensi memiliki dua makna. Pertama adalah bahwa obyek-obyek yang serupa dapat dikelompokkan sesuai dengan keseragaman dan relevansinya. Pengukuran konsistensi dalam model AHP dilakukan dalam dua tahap. Tahap pertama adalah mengukur konsistensi setiap matriks perbandingan dan tahap kedua mengukur konsistensi keseluruhan hirarki. Pengertian konsistensi itu sendiri adalah jenis pengukuran yang tak dapat terjadi begitu saja atau dengan kata lain mempunyai syarat tertentu. Suatu matriks, misalnya dengan tiga unsur (i,j dan k) dan setiap perbandingan dinyatakan dengan a, akan konsisten 100\% apabila memenuhi syarat sebagai berikut :

$$
a_{i j} \cdot a_{j k}=a_{i k}
$$

Dengan syarat tersebut, maka matriks A berikut ini dapat dinyatakan konsisten karena :

$$
\mathrm{j} \quad\left(\begin{array}{ccc}
\mathrm{i} & \mathrm{j} & \mathrm{k} \\
\mathrm{k} & 4 & 2 \\
1 / 4 & 1 & 1 / 2 \\
1 / 2 & 2 & 1
\end{array}\right)
$$

$$
\begin{aligned}
& \mathrm{a}_{\mathrm{ij}} \cdot \mathrm{a}_{\mathrm{jk}}=\mathrm{a}_{\mathrm{ik}} \longrightarrow 4 \cdot 1 / 2=2 \\
& \mathrm{a}_{\mathrm{ik}} \cdot \mathrm{a}_{\mathrm{kj}}=\mathrm{a}_{\mathrm{ij}} \longrightarrow 2 \cdot 2=4 \\
& \mathrm{a}_{\mathrm{ik}} \cdot \mathrm{a}_{\mathrm{ki}}=\mathrm{a}_{\mathrm{ji}} \longrightarrow 1 / 2 \cdot 1 / 2=1 / 4
\end{aligned}
$$

Tahap pertama, adalah mengukur konsistensi setiap matriks perbandingan. Pengukuran konsistensi dari suatu matriks itu sendiri didasarkan atas suatu eigenvalue maksimum. Dengan eigenvalue maksimum, inkonsistensi yang biasa dihasilkan matriks perbandingan dapat diminimumkan. Rumus dari indeks konsistensi $(\mathrm{CI})$ adalah sebagai berikut :

$$
\mathrm{CI}=\frac{\lambda_{\text {maks }}-\mathrm{n}}{\mathrm{n}-1}
$$

dimana :

$\lambda_{\text {maks }}=$ Nilai eigenvalue maksimum 
$\mathrm{n}=$ Ukuran matriks

$\mathrm{CI}=$ Indeks Konsistensi

Eigenvalue maksimum suatu matriks tidak akan lebih kecil dari nilai $\mathrm{n}$ sehingga tidak mungkin ada nilai CI yang negatif. Makin dekat eigenvalue maksimum dengan besarnya matriks, makin konsisten matriks tersebut dan apabila sama besarnya, maka matriks tersebut konsisten $100 \%$ atau inkonsisten $0 \%$. Sedangkan untuk menghitung rasio konsistensi (CR) dapat dilakukan dengan rumus :

$$
\mathrm{CR}=\mathrm{CI} / \mathrm{RI}
$$

dimana :

$\mathrm{CI}=$ Indeks konsistensi

$\mathrm{RI}=$ Nilai indeks acak (random value) yang nilainya ditentukan dari Tabel 3.

$\mathrm{CR}=$ Rasio konsistensi

Batasan diterima rasio konsistensi suatu matriks adalah 10\% ke bawah. Artinya, bahwa tingkat inkonsistensi di bawah $10 \%$ masih bisa diterima. Labih dari itu harus ada revisi penilaian karena tingkat inkonsistensi yang terlalu besar dapat menjurus pada suatu kesalahan.

Tabel 3. Nilai Indeks Acak (RI)

\begin{tabular}{|c|c|c|c|c|c|c|c|c|c|c|c|c|c|c|}
\hline $\mathrm{n}$ & 1 & 2 & 3 & 4 & 5 & 6 & 7 & 8 & 9 & 10 & 11 & 12 & 13 & 14 \\
\hline $\mathrm{RI}$ & 0 & 0 & 0,58 & 0,90 & 1,12 & 1,24 & 1,32 & 1,41 & 1,45 & 1,49 & 1,51 & 1,48 & 1,56 & 1,57 \\
\hline
\end{tabular}

Tahap kedua, mengukur konsistensi keseluruhan hirarki. Secara keseluruhan bahwa hirarki pun harus konsisten. Untuk menguji konsistensi hirarki digunakan hasil indeks konsistensi dan prioritas relatif setiap matriks perbandingan berpasangan pada tingkat hirarki tertentu. Rumus yang digunakan untuk menguji konsistensi hirarki adalah sebagai berikut :

$$
C R H=M / \bar{M}
$$

dimana :

$\mathrm{M}=\quad \mathrm{CI}$ level II +Bobot prioritas II.CI level III

$\overline{\mathrm{M}}=\quad$ RI level II + bobot prioritas II. RI level III

$\mathrm{RI}=\quad$ Indeks Random 
Hasil penilaian hirarki secara keseluruhan dapat diterima jika mempunyai rasio konsistensi (CRH) lebih kecil dari 10\%.

\section{Perhitungan untuk Perbandingan Berpasangan Gabungan}

Cara yang sering digunakan oleh banyak pembuat model AHP adalah dengan menghitung rata-rata penilaian dari semua responden, salah satu metode rata-rata yang sering digunakan adalah menggunakan rata-rata ukur (geometric mean). Ratarata ukur yaitu yang menyatakan akar pangkat $n$ dari hasil perkalian bilangan sebanyak $n$ responden. Kelebihan metode rata-rata ukur ini adalah selain cocok untuk bilangan rasio atau perbandingan, juga mampu mengurangi gangguan yang disebabkan oleh salah satu bilangan yang terlalu besar atau terlalu kecil. Rumus dari rata-rata ukur ini adalah sebagai berikut :

$$
\sqrt[n]{\mathrm{a}_{1} \cdot \mathrm{a}_{2} \cdot \ldots, . . \cdot \mathrm{a}_{\mathrm{n}}}=a_{w}
$$

dimana :

$\mathrm{a}_{\mathrm{w}}=$ Penilaian gabungan (penilaian akhir)

$\mathrm{a}_{\mathrm{n}}=$ Responden ke- $\mathrm{n}$

$\mathrm{n}=$ Banyaknya responden

Setelah didapatkan nilai $a_{w}$ untuk setiap sel, dibentuk sebuah matriks perbandingan berpasangan gabungan baru. Setelah itu dicari bobot atau prioritas setiap elemennya.

Untuk keperluan analisis kebijakan, responden yang dipilih berjumlah 5 (lima) orang yang berperan penting dalam upaya peningkatan Pendapatan Asli Daerah (PAD) yang bersumber dari pajak daerah di Kota Bandung, antara lain adalah instansi teknis dalam bidang perencanaan di daerah, kalangan akademisi yang sumbangan pemikirannya sebagai pengambil keputusan serta kalangan pelaku bisnis (usaha) yang pada dasarnya mampu memberikan kontribusi terhadap peningkatan PAD yang bersumber dari pajak daerah. Hasil penilaian atau perbandingan responden terhadap elemen suatu hirarki diolah dengan menggunakan program Expert Choice 2000 for Windows sehingga diperoleh bobot prioritas dan sintesa akhir (lokal dan global), serta total persepsi responden dengan menggunakan rata-rata ukur (geometric mean). 


\section{PEMBAHASAN}

Penyusunan hirarki kebijakan peningkatan Pendapatan Asli Daerah (PAD), khususnya yang bersumber dari pajak daerah Kota Bandung didasarkan pada permasalahan secara umum dan kondisi keuangan daerah. Hirarki kebijakan peningkatan penerimaan PAD yang bersumber dari pajak daerah Kota Bandung dapat dilihat pada Bagan 1. di bawah ini.

\section{Bagan 1. Hirarki Kebijakan Peningkatan Penerimaan PAD yang Bersumber dari Pajak Daerah Kota Bandung}

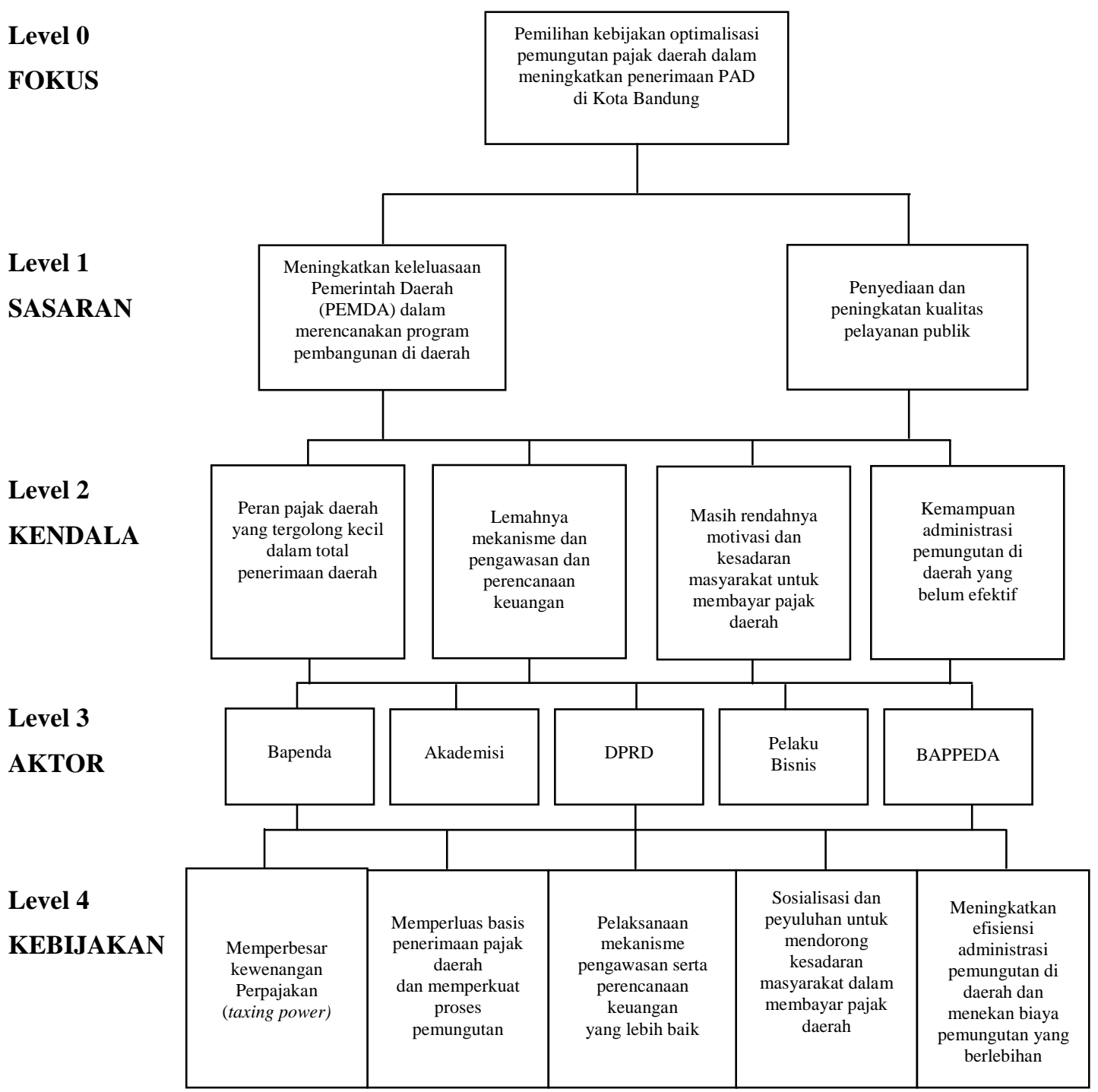


Berdasarkan pembagian jenis hirarki yang ada, maka hirarki pada bagan 1. diatas merupakan hirarki tak sempurna, dimana tidak setiap elemen pada suatu level berhubungan dengan elemen yang diatasnya.

\subsubsection{Identifikasi Setiap Level}

- Level 0 : Fokus

Fokus hirarki secara umum adalah peningkatan penerimaan Pendapatan Asli Daerah (PAD) yang bersumber dari Pajak Daerah Kota Bandung. Oleh karena itu, dengan adanya kebijakan peningkatan penerimaan Pendapatan Asli Daerah (PAD) yang bersumber dari Pajak Daerah diharapkan Kota bandung dapat menambah penerimaan daerah serta mampu membiayai pembangunan daerahnya untuk masa yang akan datang.

- Level 1 : Sasaran

Tujuan dari level sasaran adalah untuk melihat perbandingan prioritas berbagai sasaran yang hendak ingin dicapai, sehubungan dengan peningkatan penerimaan PAD yang bersumber dari Pajak Daerah di Kota Bandung. Terdapat 2 (dua) sasaran yang harus dipertimbangkan berdasarkan urutan prioritasnya. Pertama, meningkatkan keleluasaan Pemerintah Daerah (PEMDA) dalam merencanakan program pembangunan di daerah. Kedua adalah penyediaan dan peningkatan kualitas pelayanan publik kepada masyarakat.

\section{- Level 2 : Kendala}

Tujuan dari level ini adalah melihat perbandingan berbagai kendala yang mempengaruhi tercapainya sasaran yang dinginkan. Adapun kendala-kendala yang dapat mempengaruhi sasaran antara lain adalah Peran pajak daerah yang tergolong kecil dalam total penerimaan daerah, lemahnya mekanisme dan pengawasan dan perencanaan keuangan, masih rendahnya motivasi dan kesadaran masyarakat untuk membayar pajak daerah dan kemampuan administrasi pemungutan di daerah yang masih efektif.

\section{- Level 3 : Aktor atau Pelaku}

Level ini memuat pihak-pihak atau pelaku yang berpengaruh dalam mengatasi dan menyelesaikan berbagai kendala yang ada (level diatasnya). 
Bayu Kharisma. Kebijakan Optimalisasi Pemungutan Pajak Daerah ....

Sehubungan dengan hal tersebut, terdapat 5 (lima) aktor atau pelaku yang dianggap representatif dari banyak pelaku yang ada, yaitu unsur pemerintahan daerah yang terdiri dari Dipenda Kota Bandung, BAPPEDA dan DPRD Kota Bandung, dari kalangan dari akademisi, dan pelaku usaha.

\section{- Level 4 : Kebijakan}

Tujuan level ini adalah melihat perbandingan prioritas kebijakan yang dapat dilaksanakan dalam rangka meningkatkan kemampuan keuangan daerah, khususnya peningkatan PAD yang bersumber dari Pajak Daerah di Kota Bandung. Adapun alternatif-alternatif kebijakan yang diharapkan mampu meningkatkan penerimaan daerah melalui pajak daerah antara lain adalah : memperbesar kewenangan perpajakan (taxing power) daerah, memperluas basis penerimaan pajak daerah dan memperkuat proses pemungutan, pelaksanaan mekanisme pengawasan serta perencanaan keuangan yang lebih baik, sosialisasi dan penyuluhan untuk mendorong kesadaran masyarakat dalam membayar pajak daerah, meningkatkan efisiensi administrasi pemungutan di daerah dan menekan biaya pemungutan. 
Bagan 2.

Hirarki Kebijakan Peningkatan Penerimaan PAD yang Bersumber dari Pajak Daerah Kota Bandung(dengan input persepsi dari BAPPEDA kota Bandung)

Level 0

FOKUS

Level 1

SASARAN

Level 2

KENDALA

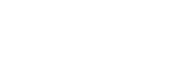

Pemilihan kebijakan optimalisas pemungutan pajak daerah dalam meningkatkan penerimaan PAD di Kota Bandung

Penyediaan dan peningkatan kualitas pelayanan publik Pemerintah Daerah (PEMDA) dalam merencanakan program pembangunan di daerah $(0,500)$

$(0,500)$

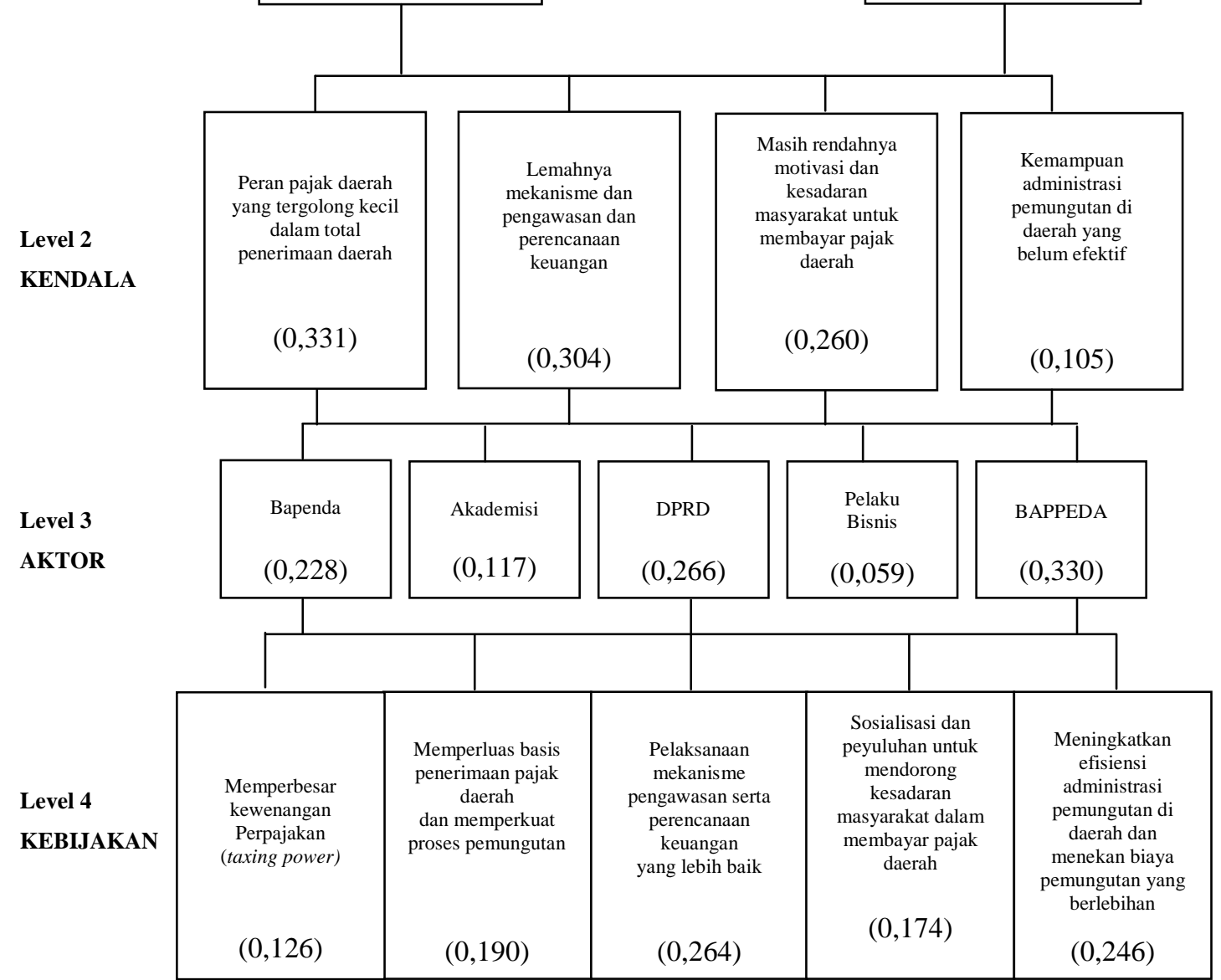

Overall Inconsistency : 0,07 
Berdasarkan hasil perhitungan berdasarkan penilaian responden BAPPEDA Kota Bandung adalah sebagai berikut :

\section{Level 1 : Sasaran}

Penilaian BAPPEDA untuk melihat perbandingan prioritas berbagai sasaran yang hendak ingin dicapai, sehubungan dengan peningkatan penerimaan PAD yang bersumber dari Pajak Daerah di Kota Bandung yaitu :

1. Meningkatkan keleluasaan Pemerintah Daerah (PEMDA) dalam merencanakan program pembangunan di daerah $(0,500)$

2. Penyediaan dan peningkatan kualitas pelayanan publik kepada masyarakat $(0,500)$

\section{Level 2 : Kendala}

Penilaian BAPPEDA dalam melihat perbandingan prioritas berbagai kendala yang mempengaruhi tercapainya sasaran yang dinginkan berdasarkan prioritas yaitu :

1. Peran pajak daerah yang tergolong kecil dalam total penerimaan daerah $(0,311)$

2. Lemahnya mekanisme dan pengawasan dan perencanaan keuangan $((0,304)$

3. Masih rendahnya motivasi dan kesadaran masyarakat untuk membayar pajak daerah $(0,260)$

4. Kemampuan administrasi pemungutan di daerah yang belum efektif $(0,105)$

\section{Level 3 : Aktor atau Pelaku}

Penilaian BAPPEDA dalam melihat perbandingan prioritas mengenai pihakpihak atau pelaku yang berpengaruh dalam mengatasi dan menyelesaikan berbagai kendala yang ada (level diatasnya) berdasarkan prioritas adalah sebagai berikut :

1. BAPPEDA Kota Bandung (0,330)

2. DPRD Kota Bandung $(0,266)$

3. Bapenda Kota Bandung $(0,228)$

4. Akademisi $(0,117)$

5. Pelaku Bisnis $(0,059)$ 


\section{Level 4 : Kebijakan}

Penilaian BAPPEDA dalam melihat perbandingan prioritas alternatif kebijakan yang dapat dilaksanakan dalam rangka meningkatkan kemampuan keuangan daerah, khususnya peningkatan PAD yang bersumber dari Pajak daerah di Kota Bandung berdasarkan prioritas adalah sebagai berikut :

1. Pelaksanaan mekanisme pengawasan serta perencanaan keuangan yang lebih baik $(0,264)$

2. Meningkatkan efisiensi administrasi pemungutan di daerah dan menekan biaya pemungutan yang berlebihan $(0,246)$

3. Memperluas basis penerimaan pajak daerah dan memperkuat proses pemungutan $(0,190)$

4. Sosialisasi dan penyuluhan untuk mendorong kesadaran masyarakat dalam membayar pajak daerah $(0,174)$

5. Memperbesar kewenangan Perpajakan (taxing power) daerah $(0,126)$ 
Bayu Kharisma. Kebijakan Optimalisasi Pemungutan Pajak Daerah ....

Bagan 3.

Hirarki Kebijakan Peningkatan Penerimaan PAD yang Bersumber dari Pajak Daerah Kota Bandung (dengan input persepsi dari BAPENDA kota Bandung)

Level 0

FOKUS

pemungutan pajak daerah dalam

meningkatkan penerimaan PAD di Kota Bandung

Level 1

SASARAN

Pemerint keleluasa

(PEMDA) dalam

merencanakan program

pembangunan di daerah

$(0,667)$

Penyediaan dan

peningkatan kualitas

pelayanan publik

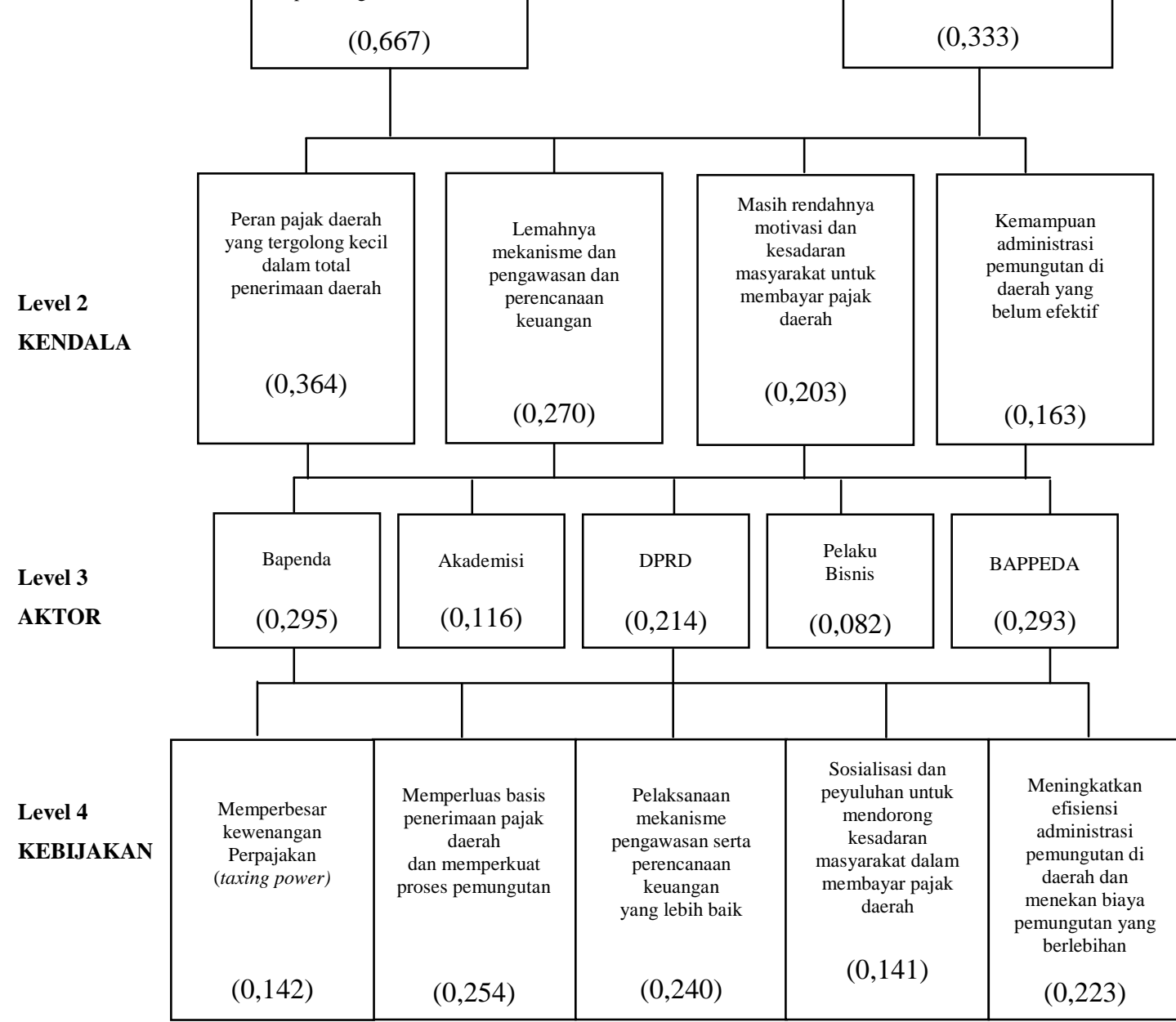

Overall Inconsistency : 0,06 
Berdasarkan hasil perhitungan berdasarkan penilaian responden Bapenda Kota Bandung adalah sebagai berikut :

\section{Level 1 : Sasaran}

Penilaian Bapenda untuk melihat perbandingan prioritas berbagai sasaran yang hendak ingin dicapai, sehubungan dengan peningkatan penerimaan PAD yang bersumber dari Pajak Daerah di Kota Bandung yaitu :

1. Meningkatkan keleluasaan Pemerintah Daerah (PEMDA) dalam merencanakan program pembangunan di daerah $(0,667)$

2. Penyediaan dan peningkatan kualitas pelayanan publik kepada masyarakat $(0,333)$

\section{Level 2 : Kendala}

Penilaian Bapenda dalam melihat perbandingan prioritas berbagai kendala yang mempengaruhi tercapainya sasaran yang dinginkan berdasarkan urutan prioritas yaitu :

1. Peran pajak yang tergolong kecil dalam total penerimaan daerah $(0,364)$

2. Lemahnya mekanisme dan pengawasan dan perencanaan keuangan $((0,270)$

3. Masih rendahnya motivasi dan kesadaran masyarakat untuk membayar pajak daerah $(0,203)$

4. Kemampuan administrasi pemungutan di daerah yang belum efektif $(0,163)$

\section{Level 3 : Aktor atau Pelaku}

Penilaian Bapenda dalam melihat perbandingan prioritas mengenai pihak-pihak atau pelaku yang berpengaruh dalam mengatasi dan menyelesaikan berbagai kendala yang ada (level diatasnya) berdasarkan urutan prioritas adalah sebagai berikut :

1. Bapenda Kota Bandung $(0,295)$

2. BAPPEDA Kota Bandung $(0,293)$

3. DPRD Kota Bandung $(0,214)$

4. Akademisi $(0,116)$

5. Pelaku Bisnis $(0,082)$

\section{Level 4 : Kebijakan}

Penilaian BAPPEDA dalam melihat perbandingan prioritas alternatif kebijakan yang dapat dilaksanakan dalam rangka meningkatkan kemampuan keuangan 
Bayu Kharisma. Kebijakan Optimalisasi Pemungutan Pajak Daerah ....

daerah, khususnya peningkatan PAD yang bersumber dari Pajak Daerah di Kota Bandung berdasarkan urutan prioritas adalah sebagai berikut :

1. Memperluas basis penerimaan pajak daerah dan memperkuat proses pemungutan $(0,254)$

2. Pelaksanaan mekanisme pengawasan serta perencanaan keuangan yang lebih baik $(0,240)$

3. Meningkatkan efisiensi administrasi pemungutan di daerah dan menekan biaya pemungutan yang berlebihan $(0,223)$

4. Memperbesar kewenangan perpajakan (taxing power) daerah $(0,142)$

5. Sosialisasi dan penyuluhan untuk mendorong kesadaran masyarakat dalam membayar pajak daerah $(0,141)$ 
Bagan 4.

Hirarki Kebijakan Peningkatan Penerimaan PAD yang Bersumber dari Pajak Daerah Kota Bandung (dengan input persepsi dari DPRD Kota Bandung)

Level 0
FOKUS

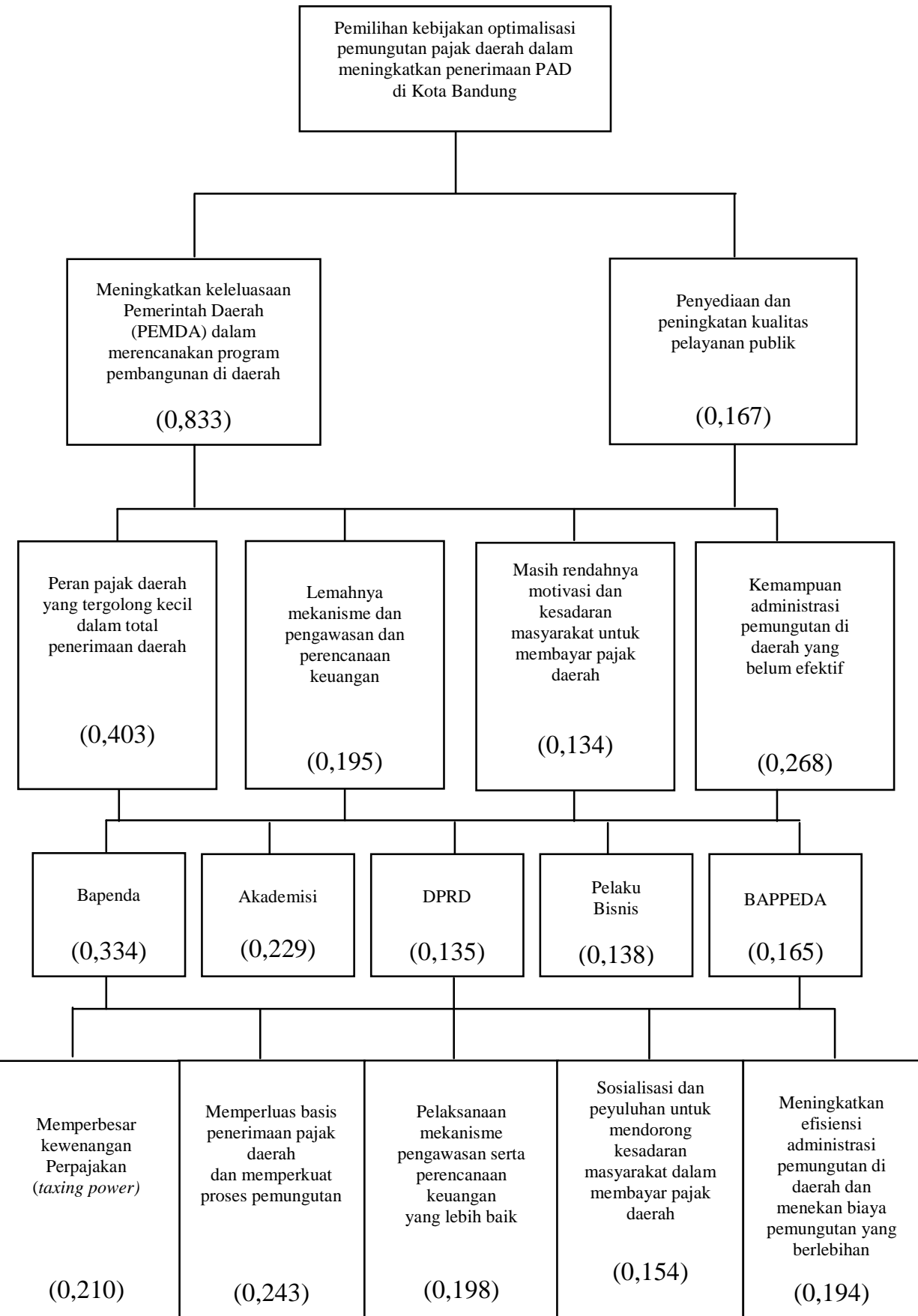

Level 1

SASARAN

Level 2

KENDALA

Level 3

AKTOR

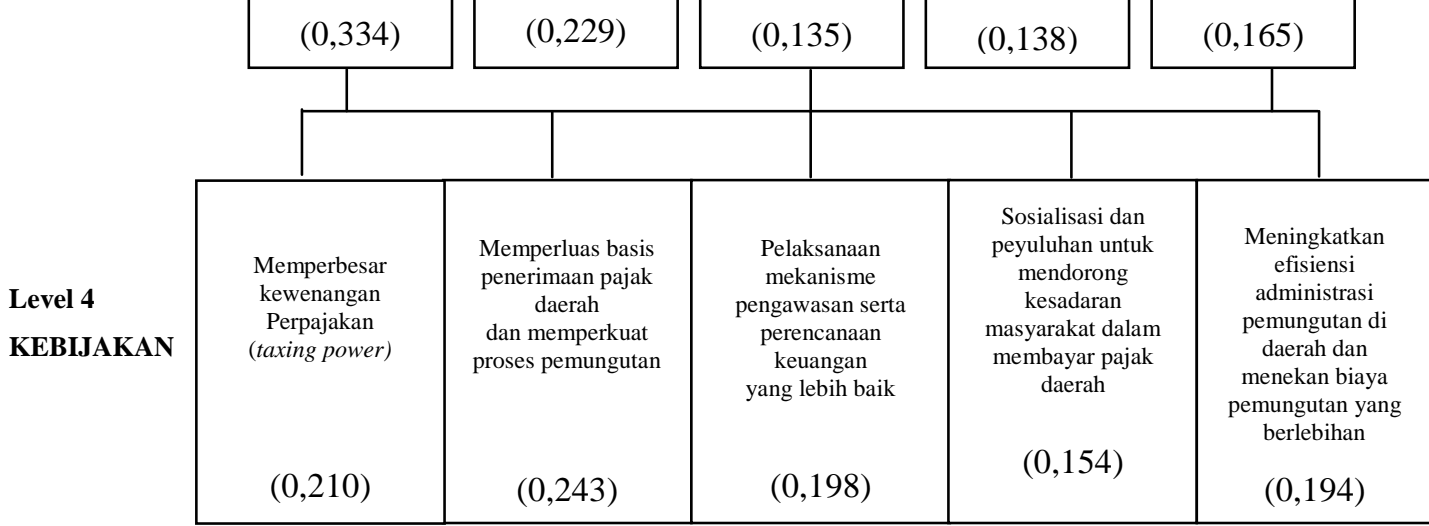

Overall Inconsistency : 0,05 
Berdasarkan hasil perhitungan berdasarkan penilaian responden DPRD Kota Bandung adalah sebagai berikut :

\section{Level 1 : Sasaran}

Penilaian DPRD Kota Bandung untuk melihat perbandingan prioritas berbagai sasaran yang hendak ingin dicapai, sehubungan dengan peningkatan penerimaan PAD yang bersumber dari Pajak Daerah di Kota Bandung yaitu :

1. Meningkatkan keleluasaan Pemerintah Daerah (PEMDA) dalam merencanakan program pembangunan di daerah $(0,833)$

2. Penyediaan dan peningkatan kualitas pelayanan publik kepada masyarakat $(0,167)$

\section{Level 2 : Kendala}

Penilaian DPRD Kota Bandung dalam melihat perbandingan prioritas berbagai kendala yang mempengaruhi tercapainya sasaran yang dinginkan berdasarkan urutan prioritas yaitu :

1. Peran pajak yang tergolong kecil dalam total penerimaan daerah $(0,403)$

2. Kemampuan administrasi pemungutan di daerah yang belum efektif $(0,268)$

3. Lemahnya mekanisme dan pengawasan dan perencanaan keuangan $((0,195)$

4. Masih rendahnya motivasi dan kesadaran masyarakat untuk membayar pajak daerah $(0,134)$

\section{Level 3 : Aktor atau Pelaku}

Penilaian DPRD Kota Bandung dalam melihat perbandingan prioritas mengenai pihak-pihak atau pelaku yang berpengaruh dalam mengatasi dan menyelesaikan berbagai kendala yang ada (level diatasnya) berdasarkan urutan prioritas adalah sebagai berikut :

1. Bapenda Kota Bandung (0,334)

2. Akademisi $(0,229)$

3. BAPPEDA Kota Bandung $(0,165)$

4. Pelaku Bisnis $(0,138)$

5. DPRD Kota Bandung $(0,135)$

\section{Level 4 : Kebijakan}

Penilaian DPRD Kota Bandung dalam melihat perbandingan prioritas alternatif kebijakan yang dapat dilaksanakan dalam rangka meningkatkan kemampuan 
keuangan daerah, khususnya peningkatan PAD yang bersumber dari Pajak Daerah di Kota Bandung berdasarkan urutan prioritas adalah sebagai berikut :

1. Memperluas basis penerimaan pajak daerah dan memperkuat proses pemungutan $(0,243)$

2. Memperbesar kewenangan Perpajakan (taxing power) daerah $(0,210)$

3. Pelaksanaan mekanisme pengawasan serta perencanaan keuangan yang lebih baik $(0,198)$

4. Meningkatkan efisiensi administrasi pemungutan di daerah dan menekan biaya pemungutan yang berlebihan $(0,194)$

5. Sosialisasi dan penyuluhan untuk mendorong kesadaran masyarakat dalam membayar pajak daerah $(0,154)$ 
Bayu Kharisma. Kebijakan Optimalisasi Pemungutan Pajak Daerah ....

Bagan 5.

Hirarki Kebijakan Peningkatan Penerimaan PAD yang Bersumber dari Pajak Daerah Kota Bandung (dengan input persepsi dari PELAKU BISNIS kota Bandung)

Level 0

FOKUS

pemungutan pajak daerah dalam

meningkatkan penerimaan $\mathrm{PAD}$ di Kota Bandung

Level 1

SASARAN

(PEMDA) dalam

merencanakan program

pembangunan di daerah

$(0,125)$

Penyediaan dan

peningkatan kualitas

pelayanan publik

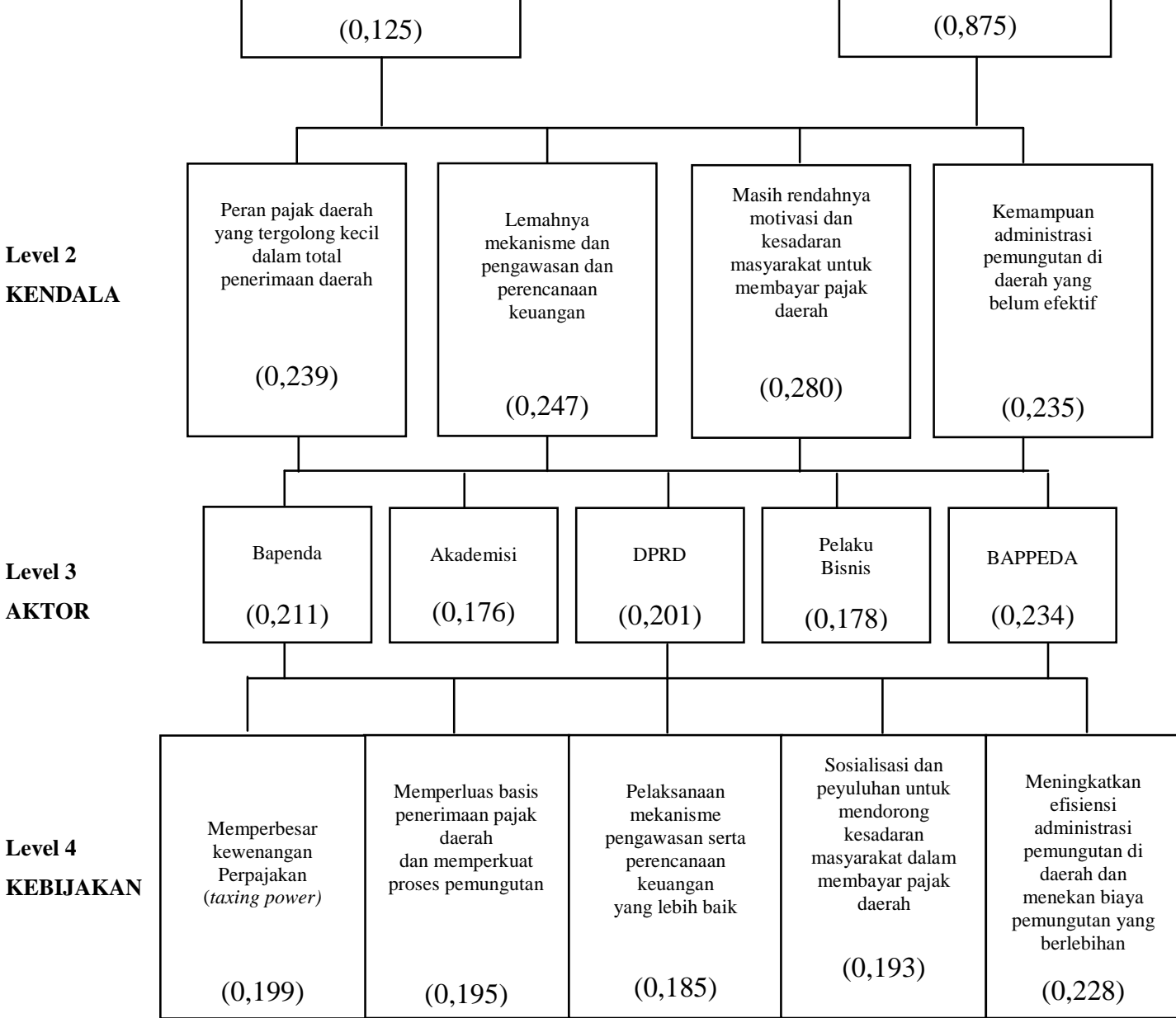

Overall Inconsistency : 0,03 
Berdasarkan hasil perhitungan berdasarkan penilaian responden pelaku bisnis adalah sebagai berikut :

\section{Level 1 : Sasaran}

Penilaian pelaku bisnis untuk melihat perbandingan prioritas berbagai sasaran yang hendak ingin dicapai, sehubungan dengan peningkatan penerimaan PAD yang bersumber dari Pajak Daerah di Kota Bandung yaitu :

1. Penyediaan dan peningkatan kualitas pelayanan publik kepada masyarakat $(0,875)$

2. Meningkatkan keleluasaan Pemerintah Daerah (PEMDA) dalam merencanakan program pembangunan di daerah $(0,125)$

\section{Level 2 : Kendala}

Penilaian pelaku bisnis dalam melihat perbandingan prioritas berbagai kendala yang mempengaruhi tercapainya sasaran yang dinginkan berdasarkan urutan prioritas yaitu :

1. Peran pajak yang tergolong kecil dalam total penerimaan daerah $(0,239)$

2. Kemampuan administrasi pemungutan di daerah yang belum efektif $(0,235)$

3. Lemahnya mekanisme dan pengawasan dan perencanaan keuangan $((0,247)$

4. Masih rendahnya motivasi dan kesadaran masyarakat untuk membayar pajak daerah $(0,280)$

\section{Level 3 : Aktor atau Pelaku}

Penilaian pelaku bisnis dalam melihat perbandingan prioritas mengenai pihakpihak atau pelaku yang berpengaruh dalam mengatasi dan menyelesaikan berbagai kendala yang ada (level diatasnya) berdasarkan urutan prioritas adalah sebagai berikut :

1. BAPPEDA Kota Bandung $(0,234)$

2. Bapenda Kota Bandung $(0,211)$

3. DPRD Kota Bandung $(0,201)$

4. Pelaku Bisnis $(0,178)$

5. Akademisi $(0,176)$

\section{Level 4 : Kebijakan}

Penilaian pelaku bisnis dalam melihat perbandingan prioritas alternatif kebijakan yang dapat dilaksanakan dalam rangka meningkatkan kemampuan keuangan 
Bayu Kharisma. Kebijakan Optimalisasi Pemungutan Pajak Daerah ....

daerah, khususnya peningkatan PAD yang bersumber dari Pajak Daerah di Kota Bandung berdasarkan urutan prioritas adalah sebagai berikut :

1. Meningkatkan efisiensi administrasi pemungutan di daerah dan menekan biaya pemungutan yang berlebihan $(0,228)$

2. Memperbesar kewenangan Perpajakan (taxing power) daerah $(0,199)$

3. Memperluas basis penerimaan pajak daerah dan memperkuat proses pemungutan $(0,195)$

4. Sosialisasi dan penyuluhan untuk mendorong kesadaran masyarakat dalam membayar pajak daerah $(0,193)$

5. Pelaksanaan mekanisme pengawasan serta perencanaan keuangan yang lebih baik $(0,185)$ 
Bagan 6.

Hirarki Kebijakan Peningkatan Penerimaan PAD yang Bersumber dari Pajak Daerah Kota Bandung (dengan input persepsi dari AKADEMISI kota Bandung)

Level 0

FOKUS

pemungutan pajak daerah dalam

meningkatkan penerimaan PAD di Kota Bandung

Level 1

SASARAN

Pemeleluasa

Pemerintah Daerah

(PEMDA) dalam

merencanakan program

pembangunan di daerah

$(0,667)$

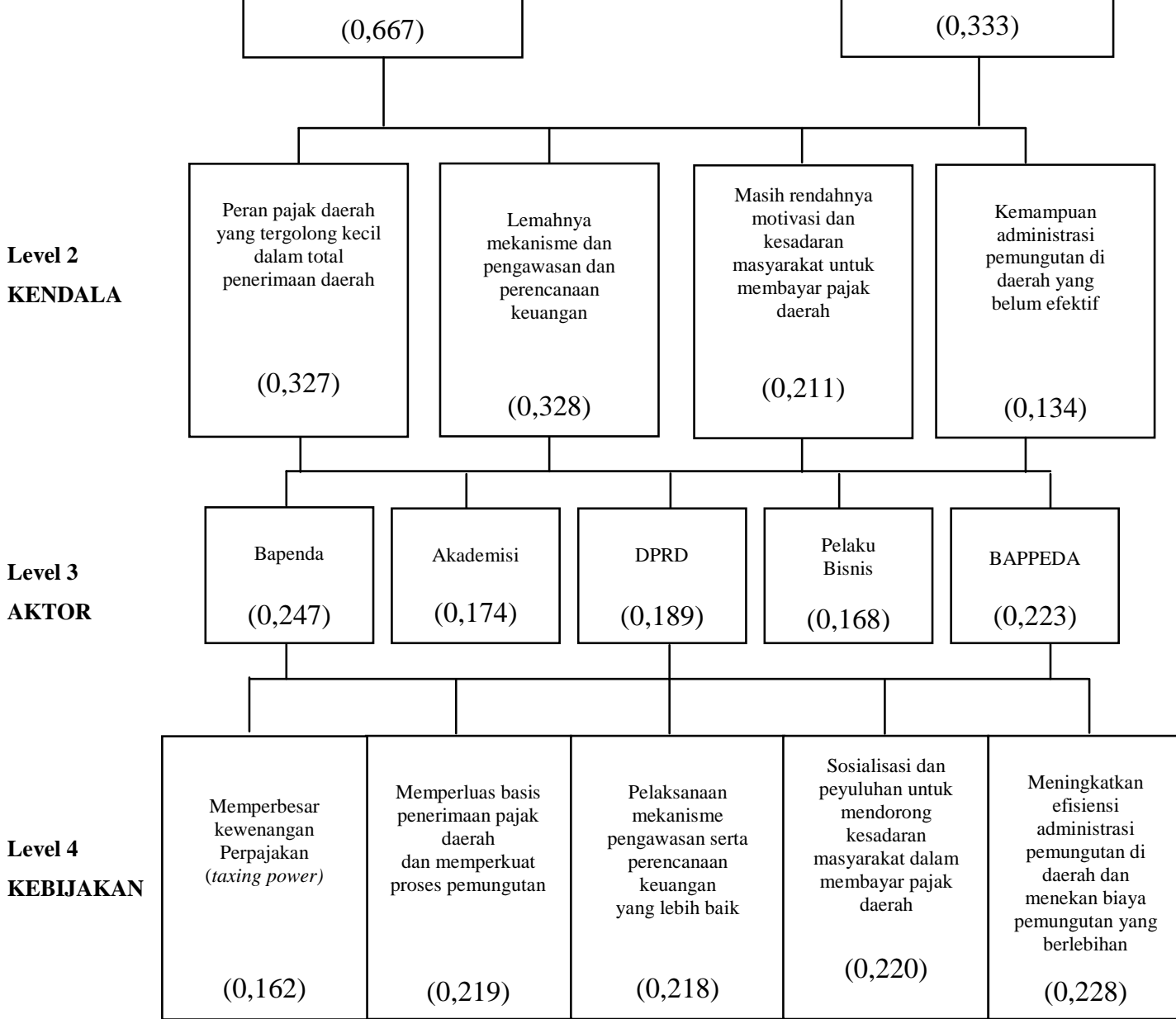

Overall Inconsistency : 0,04
Penyediaan dan peningkatan kualitas pelayanan publik

\section{$(0,333)$}

daerah yang

$(0,211)$

$(0,134)$

eningkatkan

$(0,228)$ belum efektif 
Berdasarkan hasil perhitungan berdasarkan penilaian responden akademisi adalah sebagai berikut :

\section{Level 1 : Sasaran}

Penilaian akademisi untuk melihat perbandingan prioritas berbagai sasaran yang hendak ingin dicapai, sehubungan dengan peningkatan penerimaan PAD yang bersumber dari Pajak Daerah di Kota Bandung yaitu :

1. Penyediaan dan peningkatan kualitas pelayanan publik kepada masyarakat $(0,667)$

2. Meningkatkan keleluasaan Pemerintah Daerah (PEMDA) dalam merencanakan program pembangunan di daerah $(0,333)$

\section{Level 2 : Kendala}

Penilaian akademisi dalam melihat perbandingan prioritas berbagai kendala yang mempengaruhi tercapainya sasaran yang dinginkan berdasarkan urutan prioritas yaitu :

1. Peran pajak yang tergolong kecil dalam total penerimaan daerah $(0,327)$

2. Kemampuan administrasi pemungutan di daerah yang belum efektif $(0,134)$

3. Lemahnya mekanisme dan pengawasan dan perencanaan keuangan $((0,328)$

4. Masih rendahnya motivasi dan kesadaran masyarakat untuk membayar pajak daerah $(0,211)$

\section{Level 3 : Aktor atau Pelaku}

Penilaian akademisi dalam melihat perbandingan prioritas mengenai pihak-pihak atau pelaku yang berpengaruh dalam mengatasi dan menyelesaikan berbagai kendala yang ada (level diatasnya) berdasarkan urutan prioritas adalah sebagai berikut :

1. Bapenda Kota Bandung $(0,247)$

2. BAPPEDA Kota Bandung $(0,223)$

3. DPRD Kota Bandung $(0,189)$

4. Pelaku Bisnis $(0,168)$

5. Akademisi $(0,174)$

\section{Level 4 : Kebijakan}

Penilaian akademisi dalam melihat perbandingan prioritas alternatif kebijakan yang dapat dilaksanakan dalam rangka meningkatkan kemampuan keuangan 
daerah, khususnya peningkatan PAD yang bersumber dari Pajak Daerah di Kota Bandung berdasarkan urutan prioritas adalah sebagai berikut :

1. Meningkatkan efisiensi administrasi pemungutan di daerah dan menekan biaya pemungutan yang berlebihan $(0,228)$

2. Sosialisasi dan penyuluhan untuk mendorong kesadaran masyarakat dalam membayar pajak daerah $(0,220)$

3. Memperluas basis penerimaan pajak daerah dan memperkuat proses pemungutan $(0,219)$

4. Pelaksanaan mekanisme pengawasan serta perencanaan keuangan yang lebih baik $(0,218)$

5. Memperbesar kewenangan Perpajakan (taxing power) daerah $(0,162)$ 
Bayu Kharisma. Kebijakan Optimalisasi Pemungutan Pajak Daerah ....

\title{
Hasil Sintesa Akhir Global pada Masing-Masing Responden
}

\author{
Bagan 7.
}

Hirarki Kebijakan Peningkatan Penerimaan PAD yang bersumber dari Pajak Daerah Kota Bandung (dengan input total persepsi responden)

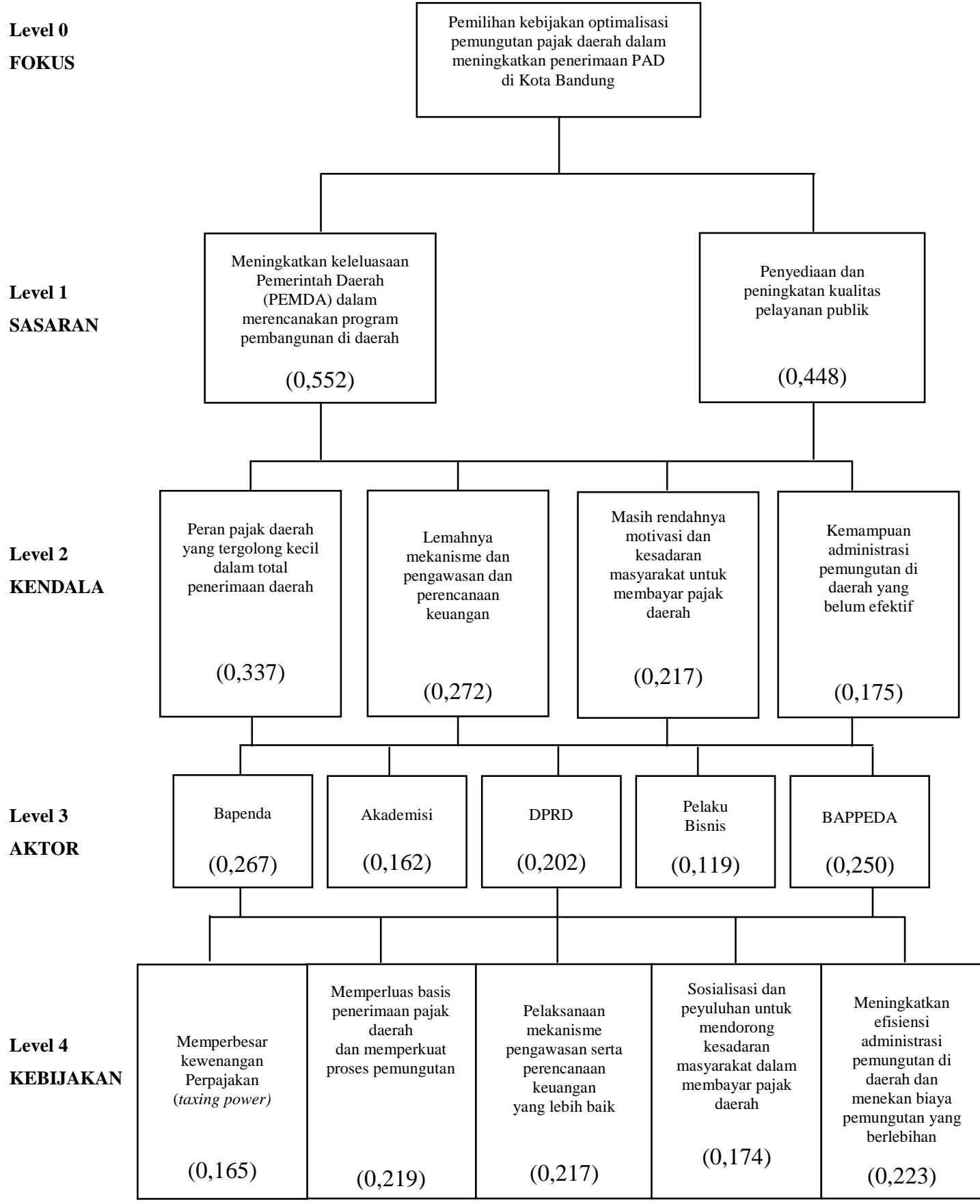

Overall Inconsistency : 0.049868 
Hasil sintesa akhir global pada masing-masing responden atau perhitungan total persepsi responden dilakukan dengan menggunakkan rata-rata ukur (geometric mean). Berdasarkan hasil perhitungan berdasarkan penilaian responden akademisi adalah sebagai berikut :

\section{Level 1 : Sasaran}

Penilaian total persepsi responden untuk melihat perbandingan prioritas berbagai sasaran yang hendak ingin dicapai, sehubungan dengan peningkatan penerimaan PAD yang bersumber dari Pajak Daerah di Kota Bandung yaitu :

1. Penyediaan dan peningkatan kualitas pelayanan publik kepada masyarakat $(0,552)$

2. Meningkatkan keleluasaan Pemerintah Daerah (PEMDA) dalam merencanakan program pembangunan di daerah $(0,0,448)$

\section{Level 2 : Kendala}

Penilaian total persepsi responden dalam melihat perbandingan prioritas berbagai kendala yang mempengaruhi tercapainya sasaran yang dinginkan berdasarkan urutan prioritas yaitu :

1. Peran pajak daerah yang tergolong kecil dalam total penerimaan daerah $(0,337)$

2. Lemahnya mekanisme dan pengawasan dan perencanaan keuangan $((0,272)$

3. Masih rendahnya motivasi dan kesadaran masyarakat untuk membayar pajak daerah $(0,217)$

4. Kemampuan administrasi pemungutan di daerah yang belum efektif $(0,175)$

\section{Level 3 : Aktor atau Pelaku}

Penilaian total persepsi responden dalam melihat perbandingan prioritas mengenai pihak-pihak atau pelaku yang berpengaruh dalam mengatasi dan menyelesaikan berbagai kendala yang ada (level diatasnya) berdasarkan urutan prioritas adalah sebagai berikut :

1. Bapenda Kota Bandung $(0,267)$

2. BAPPEDA Kota Bandung $(0,250)$

3. DPRD Kota Bandung $(0,202)$

4. Akademisi $(0,162)$

5. Pelaku Bisnis $(0,119)$ 
Bayu Kharisma. Kebijakan Optimalisasi Pemungutan Pajak Daerah ....

\section{Level 4 : Kebijakan}

Penilaian total persepsi responden dalam melihat perbandingan prioritas alternatif kebijakan yang dapat dilaksanakan dalam rangka meningkatkan kemampuan keuangan daerah, khususnya peningkatan PAD yang bersumber dari Pajak Daerah di Kota Bandung berdasarkan urutan prioritas adalah sebagai berikut :

1. Meningkatkan efisiensi administrasi pemungutan di daerah dan menekan biaya pemungutan yang berlebihan $(0,223)$

2. Memperluas basis penerimaan pajak daerah dan memperkuat proses pemungutan $(0,219)$

3. Pelaksanaan mekanisme pengawasan serta perencanaan keuangan yang lebih baik $(0,217)$

4. Sosialisasi dan penyuluhan untuk mendorong kesadaran masyarakat dalam membayar pajak daerah $(0,174)$

5. Memperbesar kewenangan perpajakan (taxing power) daerah $(0,165)$

Berdasarkan perbandingan prioritas alternatif-alternatif kebijakan dari berbagai sudut pandang instansi pemerintah yaitu Bapenda, BAPPEDA, DPRD dan kalangan akademisi serta kalangan pelaku bisnis di Kota Bandung maka rekomendasi kebijakan yang diharapkan dapat mengoptimalkan pemungutan pajak daerah dalam meningkatkan Pendapatan Asli Daerah (PAD) di Kota Bandung antara lain adalah :

1) Meningkatkan efisiensi administrasi pemungutan di daerah dan menekan biaya pemungutan yang berlebihan

Kebijakan yang dapat dilakukan oleh daerah Kota Bandung antara lain adalah memperbaiki prosedur administrasi pajak melalui penyederhanaan administrasi pajak, meningkatkan efisiensi pemungutan dari setiap jenis pemungutan dan menekan biaya pemungutan yang berlebihan sehingga dapat menimbulkan ekonomi biaya tinggi (high cost economy) dan berdampak distortif terhadap perekonomian daerah.

\section{a. Kebijakan Pajak Daerah}

Penggalian sumber-sumber keuangan daerah yang berasal dari pajak daerah pada dasarnya ditentukan oleh 2 (dua) hal, yaitu : dasar pengenaan pajak dan tarif pajak Adanya pengenaan tarif pajak yang lebih tinggi tidak selalu menghasilkan total penerimaan yang maksimal. Kondisi ini tergantung oleh respons wajib pajak 
(elasticity), permintaan dan penawaran barang yang dikenakan tarif pajak. Formulasi ini dikenal sebagai Leviathan Model (Rosen, 2005 ; Hilman, 2003) Dengan asumsi bahwa biaya administrasi perpajakan dianggap tidak berpengaruh dan ceteris-paribus level pelayanan publik yang dibiayai dari penerimaan pajak dan hanya kegiatan ekonomi saja yang dipengaruhi oleh besaran pajak. Model Leviathan ini dapat dikembangkan untuk menganalisis hubungan lebih lanjut antara tarif dan dasar pengenaan pajak untuk mencapai Total Penerimaan Pajak Maksimal.

Dalam Model Leviathan ini, menunjukkan hubungan antara tarif pajak proporsional atas basis pajak tertentu. Model Leviathan akan mencapai total penerimaan pajak maksimum $\left(\mathrm{T}^{*}\right)$ pada tarif $\mathrm{t}^{*}$. Pada tarif $\mathrm{t}^{*}$, menunjukkan bukanlah tarif tertinggi, tetapi dapat dicapai total penerimaan pajak maksimum. Pada kondisi ini dikenal sebagai Revenue Maximizing Tax Rate. Model Leviathan ini memberikan ilustrasi bahwa peningkatan penerimaan pajak daerah tidak harus dicapai dengan mengenakan tarif pajak yang terlalu tinggi, tetapi dengan pengenaan tarif pajak yang lebih rendah dikombinasikan dengan struktur pajak yang meminimalkan penghindaran pajak (tax avoidance) dan respon harga serta kuantitas barang terhadap pengenaan pajak sedemikian rupa maka akan dicapai Total Penerimaan Maksimum.

Hal ini diharapkan dapat dijadikan pertimbangan utama bagi Pemerintah Daerah dalam upaya menggali sumber-sumber keuangan yang berasal dari pajak daerah yang tidak selalu berorientasi pada pengenaan tarif yang lebih tinggi semata, namun harus memperhatikan aspek efisiensi administrasi pemungutan dan menekan biaya pengutan yang berlebihanuntuk mencapai total penerimaan yang maksimal. Untuk lebih jelasnya dapat dilihat pada Gambar 1. di bawah ini. 


\section{Gambar 2. Model Leviathan}

\section{Tarif Pajak}

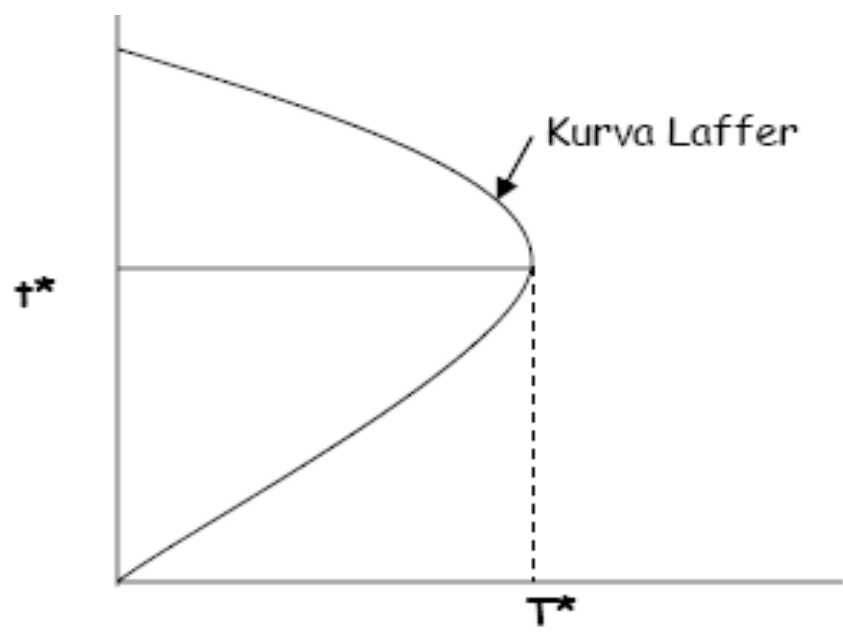

\section{Total Penerimaan Pajak}

Untuk menilai potensi pajak sebagai penerimaan daerah diperlukan beberapa kriteria, antara lain :

- Kecukupan dan elastis

Kecukupan berarti sumber pendapatan tersebut harus dapat menghasilkan pendapatan yang besar kaitannya dengan seluruh atau sebagian biaya pelayanan yang dikeluarkan. Selain itu, pemerintah menghendaki agar pajakpajak menunjukkan elastisitasnya. Artinya, kemampuan untuk menghasilkan tambahan pendapatan agar dapat menutup tuntutan yang sama atas kenaikan pengeluaran pemerintah dan dasar pengenaan pajaknya berkembang secara otomatis. Misalnya jika terjadi kenaikan harga maka pendapatan individu akan meningkat.

- Keadilan

Kriteria keadilan pada prinsipnya tercermin bahwa beban pengeluaran pemerintah haruslah dipikul oleh semua golongan dalam masyarakat sesuai antara prinsip kemampuan membayar (ability to pay) dan prinsip manfaat (benefit principle) seseorang. Pada prinsip kemampuan membayar (ability to pay), sistem pajak dipisahkan dari sisi pengeluaran publik. Perekonomian memerlukan suatu jumlah penerimaan tertentu dan setiap wajib pajak diminta untuk membayar sesuai dengan kemampuannya Pendekatan ini lebih baik dalam hal mengatasi masalah redistribusi, dimana ukuran kemampuan 
membayar mencerminkan kesejahteraan menyeluruh yang dapat diperoleh seseorang termasuk diantaranya adalah pendapatan, pola konsumsi dan kekayaan. Kemampuan membayar seseorang meningkat jika pendapatan meningkat. Prinsip ini dianggap lebih berkeadilan secara horizontal maupun vertikal. Keadilan dalam hal perpajakan daerah mempunyai dua dimensi. Pertama, adanya pemerataan secara vertikal yaitu bahwa semua orang mempunyai kemampuan yang lebih besar maka harus membayar pajak dengan jumlah yang lebih besar pula dan sebaliknya. Kedua, keadilan horizontal yaitu orang-orang mempunyai kemampuan yang sama harus membayar dengan jumlah yang sama. Sedangkan prinsip manfaat (benefit principle) menggambarkan bahwa sistem perpajakan harus adil, dimana setiap wajib pajak harus memberikan kontribusinya yang layak untuk membiayai kegiatan pemerintah daerah. Suatu sistem pajak dikatakan adil bila kontribusi yang diberikan oleh setiap wajib pajak sesuai dengan manfaat yang diperoleh dari jasa-jasa pemerintah tersebut.

- Kemampuan Administratif

Sumber pendapatan yang berbeda-beda dalam jumlah, integritas dan keputusan yang diperlukan dalam administrasinya. Pajak juga berbeda-beda dalam waktu dan biaya yang diperlukan untuk menetapkan dan memungutnya dibanding dengan hasilnya.

\section{- Kesepakatan Politis}

Keperluan politis diperlukan dalam mengenakan pajak, menetapkan struktur tarif, memutuskan siapa yang harus membayar dab bagaimana pajak tersebut dutetapkan dan memaksa sanksi terhadap para pelanggar. Hal tersebut pada gilirannya tergantung pada dua faktor kepekaan dan kejelasan dari pajak tersebut dan adanya keleluasaan dalam mengambil keputusan.

2) Memperluas basis penerimaan pajak daerah dan memperkuat proses pemungutan Kebijakan yang dilakukan untuk memperluas basis penerimaan yang dapat dipungut oleh daerah yang dalam perhitungan ekonomi dianggap potensial, antara lain yaitu mengidentifikasi pembayar pajak baru/potensial dan jumlah pembayar pajak, memperbaiki basis data objek, memperbaiki penilaian, menghitung kapasitas penerimaan dari setiap jenis pungutan. Disamping itu, 
Upaya yang dilakukan dalam memperkuat proses pemungutan, yaitu antara lain mempercepat penyusunan Perda, mengubah tarif sehingga diharapkan terciptanya tarif yang optimal, khususnya tarif retribusi dan peningkatan SDM.

3) Pelaksanaan mekanisme pengawasan serta perencanaan keuangan yang lebih baik

Hal ini dapat ditingkatkan antara lain dengan melakukan pemeriksaan secara mendadak dan berkala, memperbaiki proses pengawasan, menerapkan sanksi terhadap penunggak pajak daerah dan meningkatkan pembayaran pajak dan pelayanan yang diberikan oleh daerah. Selain itu, untuk merencanakan keuangan yang lebih baik diharapkan dapat meningkatkan koordinasi dengan instansi terkait di daerah.

4) Sosialisasi dan penyuluhan untuk mendorong kesadaran masyarakat dalam membayar pajak daerah

Melakukan sosialisasi dan penyuluhan untuk mendorong kesadaran masyarakat mengenai manfaat pajak daerah dalam pembangunan daerah.

5) Memperbesar kewenangan perpajakan (taxing power) daerah

Permasalahan lain yang berkaitan dengan PAD adalah kewenangan perpajakan (taxing power) Daerah yang sangat terbatas. Hal ini tercermin dari rendahnya kontribusi PAD terhadap APBD. Keadaan ini kurang mendukung akuntabilitas dari penggunaan anggaran daerah, dimana keterbatasan dana transfer dari Pusat untuk membiayai kebutuhan Daerah idealnya dapat ditutup oleh Daerah dengan menyesuaikan basis pajak atau tarif pajak daerahnya. Hal ini hanya dapat dilakukan apabila kebijakan taxing power dari daerah diperbesar.

\section{KESIMPULAN}

Elemen-elemen dalam menentukan kemampuan keuangan daerah untuk meningkatkan keuangan daerah, khususnya peningkatan pendapatan asli daerah yang bersumber dari pajak daerah di Kota Bandung adalah : (1) meningkatkan keleluasaan pemerintah daerah (pemda) dalam merencanakan program pembangunan di daerah; (2) penyediaan dan peningkatan kualitas pelayanan publik kepada masyarakat; (3) peran pajak yang tergolong kecil dalam total penerimaan daerah; (4) lemahnya 
mekanisme dan pengawasan dan perencanaan keuangan; (5) masih rendahnya motivasi dan kesadaran masyarakat untuk membayar pajak daerah; (6) kemampuan administrasi pemungutan di daerah yang belum efektif.

Berbagai alternatif kebijakan berdasarkan urutan prioritasnya yang mungkin dapat dilaksanakan dalam upaya meningkatkan keuangan daerah, khususnya peningkatan PAD yang bersumber dari pajak daerah di Kota Bandung adalah : (1) meningkatkan efisiensi administrasi pemungutan di daerah dan menekan biaya pemungutan yang berlebihan; (2) memperluas basis penerimaan pajak daerah dan memperkuat proses pemungutan; (3) pelaksanaan mekanisme pengawasan serta perencanaan keuangan yang lebih baik; (4) sosialisasi dan penyuluhan untuk mendorong kesadaran masyarakat dalam membayar pajak daerah; (5) memperbesar kewenangan perpajakan daerah (local taxing power)

\section{SARAN}

Penyelenggaraan otonomi daerah akan dapat dilaksanakan dengan baik apabila didukung dengan sumber-sumber pembiayaan yang memadai. Potensi ekonomi daerah sangat menentukan dalam upaya untuk meningkatkan kemampuan keuangan daerah bagi penyelenggaraan rumah tangganya. Namun demikian, otonomi daerah bukan hanya semata diukur dari jumlah PAD yang dapat dicapai tetapi lebih dari itu yaitu sejauh mana pajak daerah dapat berperan mengatur perekonomian masyarakat agar dapat bertumbuh kembang, yang pada gilirannya dapat meningkatkan kesejahteraan masyarakat di daerah. 


\section{DAFTAR PUSTAKA}

Andriani, N \& Purnawan, A (2017). “Eksistensi Pengaturan Pajak Daerah Dalam Meningkatkan Pendapatan Asli Daerah Di Pemerintah Provinsi Jawa Tengah". Jurnal Hukum Khaira Ummah Vol. 12. No. 1 Maret 2017

Hilman, A L,.(2003). "Public Finance and Public Policy : Responsibilities abnd Limitations of Government". Chambridge University Press

LKIP Dinas Pelayanan Pajak Kota Bandung Tahun 2016

Musgrave and Musgrave. (1989). "Public Finance in Theory and Practice". $5^{\text {th }}$ ed. Mc-Graw Hill.

Perda APBD, Ditjen Bina Keuangan Daerah Kementerian Dalam Negeri, 2016

Puspitasari,E.R.A (2014). “ Analisis Efektivitas, Efisiensi, dan Kontribusi Pajak Dan Retribusi Daerah Terhadap Pad Kabupaten Blora Tahun 2009-2013”. Fakultas Ekonomika Dan Bisnis Universitas Diponegoro Semarang

Purwadinata, S (2010) "Analisis Potensi Pendapatan Asli Daerah dan Strategi Peningkatan Kemampuan Keuangan Daerah : Studi di Kabupaten Sumbawa, Indonesia”. Disertasi FEB Universitas Brawijaya

Riduansyah, M. (2003). “Kontribusi Pajak Daerah dan Retribusi Daerah terhadap Pendapatan Asli Daerah (PAD) dan Anggaran Pendapatan dan Belanja Daerah (APBD) Guna Mendukung Pelaksanaan Otonomi Daerah (Studi Kasus Pemerintah Daerah Kota Bogor". Makara, Sosial Humaniora, Vol. 7, No. 2, Desember 2003

Rosen, H.S. (2005). “Public Finance”, $7^{\text {th }}$ ed. Mc-Graw Hill.

Sidik, M, (2002). Perimbangan Keuangan Pusat dan Daerah Sebagai Pelaksanaan Desentralisasi Fiskal. Jakarta

Sidik, M, (2003). "Format Hubungan Keuangan Pemerintah Pusat dan Daerah Yang Mengacu Pada Pencapaian Tujuan Nasional”. Bunga Rampai Desentralisasi Fiskal. Departemen Keuangan, Jakarta

Saaty, T.L (1989). Decision Making For The Leaders : Analytical Hirarchy Process for Decisions in A Complex World. ${ }^{\text {rd }}$. RWS Publications. Pittsburgh 